PROCEEDINGS OF THE UNITED STATES NATIONAL MUSEUM

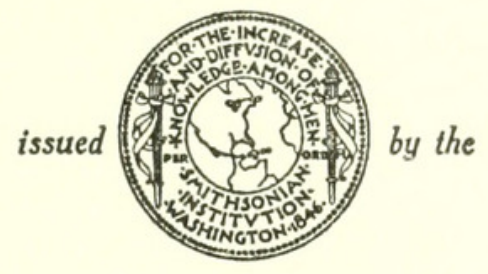

SMITHSONIAN INSTITUTION

U. S. NATIONAL MUSEUM

\begin{tabular}{lll}
\hline \hline Vol. 108 & Washington : 1958 & No. 3399 \\
\hline \hline
\end{tabular}

\title{
REVISION OF THE MILLIPED GENUS PACHYDESMUS (POLYDESMIDA: XYSTODESMIDAE)
}

By Richard L. Hoffman ${ }^{1}$

Southeastern United States, from South Carolina and Tennessee to Louisiana, is the home of Pachydesmus, a xystodesmid genus whose species include the largest known polydesmoids of North America. Despite their great size and the relatively wide range of the group, however, individuals of Pachydesmus appear to be scarce or secretive. Since the first species was appropriately named Polydesmus crassicutis by $\mathrm{H}$. C. Wood in 1864, only nine names have subsequently been founded upon members of the genus, and less than a hundred specimens are at present contained in the major collections.

It is, in a way, fortunate that no more extensive work has been done on the genus - at least work of the careless descriptive kind which has been characteristic of American diplopodology and which is still being published by a few investigators. Although no attempt has ever been made to assemble what is known about Pachydesmus, and the published descriptions and drawings are nearly useless for comparative purposes, the scarcity of specimens has at least limited the confusion to a fraction of that which prevails in certain other genera.

The general plan of the present study is not pretentious. The two primary considerations affecting its course have been the evaluation of all specific names based upon pachydesmids and the provision of accurate illustrations of those forms which appear to be valid-these being the aspects of diplopod taxonomy most in need of immediate

1 Department of Biology, Virginia Polytechnic Institute, Blacksburg, Va. 
attention. In addition, however, it has been possible to devote some attention to the secondary considerations such as variability, geographic distribution, and relative taxonomic status of the various forms.

In addition to establishing a degree of stability in the genus, and providing a means for other workers to identify their specimens with confidence, the present paper may serve another purpose, that of emphasizing the desirability that such studies might become the rule rather than the exception. It is a matter of regret that most of the work still being done on diplopods consists merely of brief descriptions of miscellaneous new forms, with little or no attempt at integration with existing facts. This approach is in no way different from, much less superior to, the work of the catalogers of the early 19th century, and serves only the isolated purpose of providing names for taxonomic entities with as little consideration as possible. Furthermore, it contributes nothing to the general knowledge of evolution in the Diplopoda, it confuses an already difficult situation (particularly from the standpoint of the beginner), and produces a volume of unrelated facts which must eventually be assembled, evaluated, and reorganized before they acquire any significance. By contrast, the treatment of entire genera with some concern for thoroughness requires only slightly more labor, and the result is undeniably more attractive and useful for all concerned.

For the preceding reasons, plus the fact that material of most of the named forms was at hand or readily available, I was prompted several years ago to undertake a revision of Pachydesmus, which is now offered to my colleagues and successors with the belief that I am leaving the genus in somewhat better condition than I found it.

\section{Materials and Methods}

During the preparation of this paper, I have examined a total of 68 specimens of Pachydesmus, representing all of the forms considered to be valid. This material is contained in seven collections, which are listed, with the abbreviations used for their designation, as follows:

AMNH: American Museum of Natural History, New York, N. Y.

CNHM: Chicago Natural History Museum, Chicago, Ill.

MCZ: Museum of Comparative Zoology, Cambridge, Mass.

NBC: Private collection of Nell B. Causey, Fayetteville, Ark.

RLH: $\quad$ Private collection of R. L. Hoffman, Blacksburg, Va.

RVC: Private collection of Dr. R. V. Chamberlin, Salt Lake City, Utah.

USNM: U. S. National Museum, Washington, D. C.

In many instances, it happens that the value of a systematic paper is directly proportional to the number of type specimens examined by the author. This is particularly true in the case of diplopods, especially when the original description included inadequate illustrations 
or none at all. I have been fortunate, in this respect, in being able to study the types of five of the ten names based upon species of Pachydesmus. These are:

Fontaria clara Chamberlin 1918, in MCZ

Pachydesmus retrorsus Chamberlin 1921, in MCZ

Pachydesmus duplex Chamberlin 1939, in RVC

Pachydesmus simulans Chamberlin 1942, in RVC

Pachydesmus denticulatus Chamberlin 1946, in RVC

Material undoubtedly conspecific with the types has been seen of all of the remaining names except Fontaria louisiana Chamberlin, the status of which is still uncertain. The holotype of Fontaria laticollis Attems was in the Berlin Museum and not readily available, but in this case, as also with Pachydesmus incursus and P. kisatchinsis Chamberlin, specimens are at hand which match the original descriptions in every respect. Two very old specimens from Mississippi in the U.S. National Museum may possibly be part of the type series of Polydesmus crassicutis Wood.

The illustrations in this paper were made with the use of a binocular microscope fitted with an ocular reticule, with great care being taken to orient the structures into approximately the same position before the drawings were made. Copulatory structures were removed in all cases, and adherent membrane and muscle tissue dissected away. Measurements of total length of specimens were made as uniformly as possible, care being taken to avoid undue stretching or compressing of the animals. Such measurements are probably accurate to about a millimeter or two of being the correct length.

\section{ACKNOWLedgments}

For the loan of, or access to, much of the material studied, I am indebted to Henry S. Dybas and R. L. Wenzel and Drs. W. J. Gertsch, J. F. G. Clarke, P. J. Darlington, and N. B. Causey. Dr. Ralph V. Chamberlin is due a special note of thanks for his generous loan of type specimens without which this work could not have been completed. For the material in my collection, I am deeply grateful to Dr. Ralph E. Crabill, Jr., to Dr. Robert W. Lichtwardt, and particularly to my good friend Leslie Hubricht, who, during his field work in connection with terrestrial mollusks, has obtained more pachydesmids than all other collectors combined.

\section{Review of the Literature}

The first species of Pachydesmus to be described was named in 1864 by H. C. Wood. His description of Polydesmus crassicutis, although brief, was quite accurate, and the woodcut illustration of the male gonopod published a year later in the "Myriapoda of North America" is detailed enough to show the characters now considered to be diag- 
nostic for crassicutis in its present restricted sense. Wood's material, borrowed from the Smithsonian Institution, was collected in southern Mississippi.

No further reference to the genus appeared until 1888, when Charles H. Bollman recorded Fontaria crassicutis from Indian Springs, Ga.

In 1895 , crassicutis was designated by O. F. Cook as the type species of his new genus Pachydesmus, one of the six genera originally included in Cook's family Xystodesmidae.

The great monograph of the polydesmoids written by Carl Attems and published in 1899 and 1900 contained the description of a second member of the genus. Since Attems did not recognize Cook's new genera, his species was proposed as Fontaria laticollis. The type specimen was said to have come from Illinois, doubtless through some kind of error, as laticollis is known with certainty only from central Tennessee, and no members of the genus have been found in or near Illinois.

In writing on miscellaneous American diplopods, Brolemann (1900) published a good figure of the gonopods of crassicutis, from a Louisiana specimen. Brolemann, as well as Attems, disregarded the name Pachydesmus, preferring to retain the old usage of Fontaria for most of the xystodesmid species.

Thus, during the half century following the description of crassicutis, only one additional species had been named, and less than half a dozen references to them had been made in the literature. During the very active career of $R$. V. Chamberlin, however, a considerable number of new forms have been described, and in recent years several other workers have dealt with the genus at least cursorily. Dr. Chamberlin described Fontaria clara and F. louisiana in 1918, Pachydesmus retrorsus in 1921, $P$. duplex and $P$. incursus in 1939, P. simulans and $P$. kisatchinsis in 1942, and P. denticulatus in 1946.

In his final great treatise on the Polydesmida, Count Attems (1938) accepted Pachydesmus as a valid genus, but combined with it the genus Harpaphe Cook of the Pacific Coast region! Although there is some similarity in the gonopods of the two genera, numerous other characters prohibit any close association of them, much less postulation of their identity. Attems included crassicutis, laticollis, and intaminatus in his treatment of Pachydesmus, with retrorsus added in the status of an "unsichere Art."

Loomis (1943) recorded retrorsus from northeastern Alabama, on the basis of material collected by Hubricht. In 1948, Loomis and Hoffman placed Pachydesmus kisatchinsis Chamberlin in the synonymy of Fontaria clara Chamberlin, bringing the latter name into Pachydesmus for the first time. Finally, Causey (1955) has recorded $P$. 
clarus from several localties in western Louisiana, and recorded the color pattern of the species.

To the present time, therefore, ten specific names have been based upon specimens referable to the genus Pachydesmus, with characters of the male gonopods forming the sole basis for recognition. However, since published illustrations of the gonopods have been made from a diversity of aspects, rarely any two being the same, differences leading to the separation of presumed new species have been much more apparent than real, as the drawings made for this study will reveal. I believe that the genus contains but two species, $P$. clarus Chamberlin and $P$. crassicutis Wood, most of the other names representing merely geographic races of the latter.

\section{Taxonomic Characters}

Although its species can readily be distinguished by nonsexual characters from the species of other genera occurring in the same region, the genus Pachydesmus is diagnosed primarily upon the configuration of the male gonopods. The unusual secondary process of the telopodite, which appears to be derived from the strongly chitinized tibiotarsal region rather than from the prefemur, occurs in both of the species and serves as a unifying character although the body structure differs more between $P$. clarus and $P$. crassicutis than between species of various distinct genera in other sections of the Xystodesmidae. Although there can scarcely be any doubt that the two are congeneric, their dissimilarities indicate a very remote period of divergence and subsequent isolation.

Although members of the Crassicutis Group are immediately recognizable by their large size and laterally attenuated collum, it is difficult to formulate a generic diagnosis not based on gonopod structure since females of clarus do not present any unusual features and are not very similar to those of crassicutis. A peculiarity of females of both species, however, is the rather large cephalomesial lobe of the pleuron of the $3 \mathrm{~d}$ segment (discussed further on in this section), which may prove to be constant and stable for generic recognition. Once a specimen is placed in Pachydesmus, the matter of its identification becomes rather simple.

Size of Body: Insofar as can be determined with the limited material at hand, variation in the size of mature specimens appears to be correlated with populations recognizable on the basis of structural features. Figure 2 indicates the range in length (to the nearest millimeter) of specimens of the recognized forms of the genus. Apparently an over-all range of about $10 \mathrm{~mm}$. is to be expected for each, and although some cases of overlap occur, certain forms can be separated solely on the basis of length, and this variable should clearly be helpful 
in identifying females. Generally, the forms which are closest in body size are also quite similar in gonopod structure and are usually geographically approximate. Variability of size is thus one of interest in the consideration of phylogeny and relationships within the genus. There is a distinct tendency for the smaller forms to be dispersed around the periphery of the generic range (fig. 3).

Shape of COLlum: In the subspecies of crassicutis the collum is attenuated laterally and extends as much as a millimeter or more beyond the paranota of the following segments (fig. 1,a). This character was noted by Attems in the pachydesmid which he described in the "System der Polydesmiden" and is the basis of the name laticollis. In clarus, however, the collum is of normal shape (fig. 1,b) and thus provides a fundamental means of distinguishing between the two species. No variation in shape has been noted between any of the eight geographic races of crassicutis, nor does there seem to be any sexual dimorphism in this character.

Color pattern: Very little is known of the colors of living individuals of Pachydesmus, and therefore little can be said about the taxonomic value of pigmentation. Judging from recently preserved specimens, the large forms related to laticollis (retrorsus, hubrichti, adsinicolus) appear to be light brown dorsally, with the paranota rather testaceous. Around the periphery of the range, the colors become more distinctive, clarus being black with the paranota coral red or pink, duplex blackish with yellow paranota, and incursus brown with either pink or yellow paranotal markings. The presence of reds and yellows is almost universal in the Xystodesmidae, so that the loss of such hues may be considered a specialization concomittant with increase in size.

Interzonal FurRow: The interzonal furrow is quite similar in both clarus and crassicutis, at least that part which crosses the dorsum. Ventrally, however, it becomes a well-defined and sharply margined groove in clarus, but is reduced to a mere transverse suture across the sterna in the forms of crassicutis.

GoNopods: Characters afiorded by the conspicuous external gonopods of many diplopods were utilized in the diagnosis of new species as long ago as 1832, but did not receive real emphasis until a half-century later. Since about 1884 there has developed a tendency to rely more and more exclusively upon male genitalia, despite which fact numerous workers have never given more than superficial sketches of the appendages, accompanied by no description whatever. That such important structures should have received so little close study is somewhat astonishing. An attempt has been made in this study to illustrate the gonopods from the same aspect for accurate comparisons, and to devise a tentative terminology by which differences can be 
expressed verbally in an intelligible manner. Although H. C. Wood, the describer of the first known pachydesmid, himself recognized the taxonomic value of female genitalia, and provided woodcut illustrations of them in his "Myriapoda of North America" (1865), only sporadic attempts to develop the knowledge of the structure and systematic utility of the cyphopods have been made by his American successors. These structures, as shown in the accompanying drawings, pronounce their own silent indictment of their long and unseeming neglect.

The gonopods of the male sex in Pachydesmus are unusual in their development of a secondary tibiotarsus which equals or exceeds the primary branch in size. In other respects the gonopods are more or less typical for the family. The coxae are large, and loosely attached to each other by membrane only.

On the anterior surface each coxa bears two long macrosetae and a fairly large coxal apophysis or condyle of various shape. As a general rule, this process is largest in specimens from the center of the generic range, where it is often crenulate as well. In clarus, the coxal apophysis is smallest, forming merely a small subconical lobe.

The telopodite joint is massive and composed of three distal branches. The smallest of these is the prefemoral process, arising adjacent to the swollen and setose prefemoral portion, and directed distad, bent at an obtuse angle at about its midlength, becoming attenuated and acuminate terminally. The main division of the telopodite is nearly straight and is divided into a densely setose basal portion probably consisting of the prefemur and femur, and a thin, bladelike distal portion representing the tibiotarsus. On the lateral side of the telopodite, near its base, a large process originates, directed first proximad and then, by a strong bend, distad parallel to the main blade. This large process is structurally similar to the chitinized tibiotarsal area, and may be tentatively considered as a secondary tibiotarsus. Distally it may be simple and acuminate, or bifid and elaborated.

The telopodite portion of the gonopod presents several variable features. The relative length of the prefemoral portion with respect to the entire joint (as determined with an ocular micrometer) varies geographically, and again the variation is centrifugal in that in laticollis and retrorsus the prefemur attains its greatest proportion of the total length -70 percent. Toward the periphery, this ratio decreases to 60 percent in crassicutis and incursus, and 58 percent in clarus, the decrease being roughly proportional to the magnitude of the geographic separation involved. Another feature showing strikingly similar geographic parallelism is the denticulation of the anterior edge of the tibiotarsus. This edge becomes serrate in most of the marginal 
forms, including duplex, crassicutis, denticulatus, and incursus, while remaining smooth and entire in laticollis, retrorsus, hubrichti, and adsinicolus (fig. 4).

The secondary tibiotarsus is bulkiest near the center of the generic range, where it is also distally modified into a $T$ or $Y$ shape. The marginal forms tend to have a smaller process, with the terminal modification much simpler. In crassicutis crassicutis the subterminal process is rather small and visible only in a sublateral aspect, in crassicutis duplex it is missing entirely. The secondary tibiotarsus of clarus is reduced to a rather short acicular process much smaller than the primary branch.

Aside from the obvious differences mentioned in the preceding paragraphs, the general shape of the gonopods in the different forms is distinctive for each, embodying numerous elements of shape and proportion difficult to describe verbally.

Sternal knobs: In males of the crassicutis group, the podosternites of the midbody segments are produced into transversely elongated swellings between the posterior legpair. Usually two or three of the sternites posterior to the gonopods are flat, with a median cruciform impression, caudad of which the sternal knobs form a continuous series back to the 16 th or 17 th segment. These swellings are not present in males of $P$. clarus. Their appearance in the males of some species of Epeloria suggest a line of relationship which is augmented by the presence of a somewhat broadened collum in certain forms of that genus.

Cyphopod aperture: Females of Pachydesmus appear to be characterized by a specialization affecting the vicinity of the $2 \mathrm{~d}$ legpair. The anterior margin of the pleurotergite of the $3 \mathrm{~d}$ segment is produced cephalomesiad into a distinct rounded lobe on each side of the body, these lobes extending partially in front of the coxae of the $2 \mathrm{~d}$ pair of legs. The margin of the pleurotergite immediately posterior to the lobes is raised into a high marginal flange.

Cypноpods: In the material available to me, females of only five forms are represented. In these, however, the shape of the cyphopods is so distinctive that the structures would seem to be readily available for diagnostic purposes. Furthermore, there seems to be structural divergence and similarity on a par with, and correlated with, variation in the gonopods. For instance, the females of the closely related forms laticollis, hubrichti, and retrorsus obviously are quite similar in genital characters (fig. 5,a,c), in that the receptacle (R) is not longer than the valves, and is distinctly obliquely excavated distally, leaving a pronounced shelf just beneath the outer valve. In the female of the more disjunct $P$. crassicutis duplex, the receptacle (fig. 5,e) is extended distad considerably beyond the ends of the valves, and its 
entire shape is quite different from that of the other three subspecies enumerated.

\section{Genus Pachydesmus Cook}

Pachydesmus Cook, 1895, p. 5.-Pocock, 1909, p. 188.-Attems, 1938, p. 153.Chamberlin and Hoffman, 1958, p. 42.

Type species: Polydesmus crassicutis Wood 1864, by original designation.

Diagnosis: A genus of moderate to large, rather bulky xystodesmids of variable structure with the following characteristics:

Head smooth and polished, the vertigial groove terminating anteriorly in a small but distinct interantennal depression; two frontal, two subantennal, and four supra-antennal setae present; antennae slender and moderately long, extending caudad to middle of $3 \mathrm{~d}$ tergite, with four sensory cones; genae somewhat swollen and with distinct median grooves.

Paranota moderately developed, slightly less than a third as wide as diameter of body cavity, continuing or but slightly interrupting slope of dorsum. Pores normal in distribution, opening on the dorsal side of the peritremata. Tergites very finely coriaceous, often with several transverse rows of very tiny setiferous tubercules.

Sterna smooth and completely glabrous, not produced at the bases of legs, podosterna appreciably raised above level of prozonites. Pleura finely granular, without ridges or clusters of tubercules. No processes or knobs between 3d and 6th legpairs of the male.

Coxae of gonopods large, connected only by sclerotized membrane, there being no zygomatic structure; each coxa with two elongate macrosetae and a coxal apophysis of variable size above the origin of the solenite. Prefemur elongated from a slightly globose base, densely setose, with a moderately large, slender, weakly chitinized prefemoral process which is bent at an obtuse angle at about its midlength. Acropodite of gonopod (coalesced femur and tibiotarsus) a thin, heavily sclerotized blade with distinct seminal groove and distally bent at a right angle. A large secondary tibiotarsal branch originates at the base of the telopodite, and is bent strongly distad, subparallel to and usually as long as the main branch, often modified distally with a subterminal spur of variable size and shape.

Anterior edge of ventral ends of pleurotergites of the $3 \mathrm{~d}$ segment in females produced cephalomesiad into a large rounded elongate lobe which partially extends in front of the coxae of the second pair of legs. Immediately caudad to these lobes the pleurotergite is produced into a rather high, thin, marginal flange.

Cyphopods large and conspicuous, of the characteristic polydesmoid form and not strikingly different from those of other xystodesmid $455980-58-2$ 
genera, although manifesting distinct specific and subspecific characters in the shape of the receptacle and valves.

$\mathrm{R}_{\mathrm{ANGE}}$ : Southeastern United States, from extreme western South Carolina and eastern Tennessee south and west through Georgia and Alabama to Mobile Bay, the Mississippi Delta, and the upland parishes of northwestern Louisiana, north through Mississippi into extreme southwestern Tennessee.

Species: Two, separable by the characters stipulated in the following key.

\section{Key to the species of Pachydesmus}

1. Small species, less than $50 \mathrm{~mm}$. in length; collum not wider than the following tergite; interzonal furrow open and distinct across sternites; femora of legs longer than coxae and prefemora combined; podosterna of males without transverse ridge between the second legpair . . . clarus Chamberlin (p. 190)

Larger species, from 50 to $80 \mathrm{~mm}$. in length; collum considerably wider than the following tergite; interzonal furrow reduced to a mere suture across sternites; femora of legs about equal in length to the prefemora; podosterna of segments $10-17$ of males with distinct transverse ridge between the caudad legpair. . . . . . . . . . . . . . crassicutis Wood (p. 195)

\section{Pachydesmus clarus (Chamberlin)}

Figures $1, b, 6$

Fontaria clara Chamberlin, 1918b, p. 372.-Attems, 1938, p. 167.

Pachydesmus kisatchinsis Chamberlin, 1942, p. 4, fig. 8 (Kisatchi, Natchitoches Parish, La., type in Chamberlin collection).

Pachydesmus clarus Loomis and Hoffman, 1948, p. 53.-Causey, 1955, p. 25.Chamberlin and Hoffman, 1958, p. 43.

Type specimens: Male holotype and paratypes of both sexes (MCZ), male paratype (USNM 2323), collected at Creston, Natchitoches Parish, La., by Karl P. Schmidt in February and March 1915.

Diagnosis: A small species of Pachydesmus separable from crassicutis by the characters stipulated in the foregoing key to species. The reduction of the secondary tibiotarsus to a shortened acicular spine and the corresponding diminuation of the coxal apophysis are additional specific characters peculiar to the male sex.

Description: Of male paratype: Length, $48 \mathrm{~mm}$., width of 10 th segment, $9.0 \mathrm{~mm}$. Segments $5-15$ of approximately same width.

Front of head smooth and polished, vertigial groove rather deep just above level of antennae; genae inflated and with distinct median impressions. Two frontal, two subantennal, and four supra-antennal setae present. Antennae set rather close at base, separated by a distance considerably less than length of $2 \mathrm{~d}$ article. Articles 2-4 similar in size and shape, 6th about same length but less clavate, 7 th semiglobose with four well-separated bacilliform sensory cones. Articles 1-3 almost glabrous, $1-5$ with five or six macrosetae at their distal 

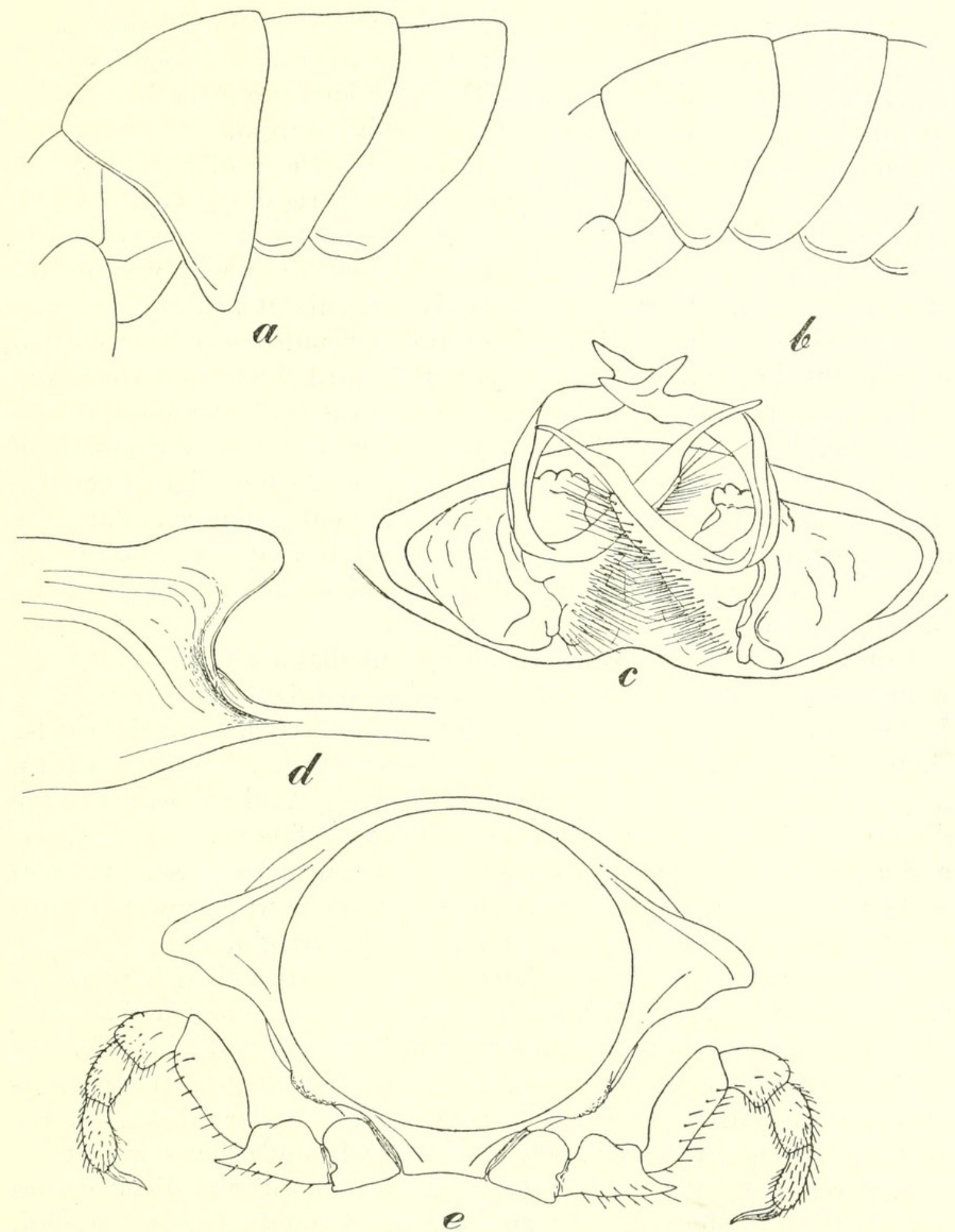

Figure 1.-Structural details of Pachydesmus: a, anterior end of body, lateral aspect, of $P$. crassicutis crassicutis; $b$, same, of $P$. clarus; $c$ male gonopods, in situ, of $P$. c. retrorsus; $d$, pleural lobe of $3 \mathrm{~d}$ segment of female of $P$. c. duplex; $e$, caudal aspect of a midbody segment of $P$. c. crassicutis.

end, 5-7 becoming more setose, the setae of article 7 fine, short, and procumbent.

Collum not quite as wide as $2 \mathrm{~d}$ tergite, its anterior and posterior margins straight and parallel across the middle, both edges tapering: laterally (fig. 1,b). Anterior half of lateral ends bent obliquely 
cephaloventrad; anterior edge slightly sinuate, distinctly margined. Surface of collum very finely coriaceous, with a row of eight widely separated, very small setae near the anterior margin and a similar row of ten such setae paralleling the caudal margin.

Paranota of segments $2-4$ swept forward, those of segments 5-8 nearly transverse, the remainder becoming increasingly bent caudad. Anterior corners of all paranota rounded, the posterior corners obtusely angled back to 7th segment, caudad of which the angle becomes increasingly acute. Paranota moderately wide, about a third the diameter of the body cylinder, those of anterior segments continuing slope of dorsum but becoming nearly horizontal toward the rear of the body; anterior edges set off by an acute ridge and shallow depression, lateral edges merely tumid and shining; pores opening on the dorsal side of swelling, exactly halfway along its length; caudal edges slightly convex, meeting the edge of metazonite proper at a re-entrant angle. Paranota of 18th segment forming elongate triangular lobes which extend caudad to level of the caudal margin of 19th, lobes of the latter segment short, broadly rounded.

Dorsal surface of metatergites finely but distinctly coriaceous, set with a large number of very tiny setiferous tubercules. Interzonal furrow broad, deep, and finely costulate. Anal segment much broader than long, its median projection short and distally truncate, with a large setiferous knob at the base on each side. Anal valves with very distinct swollen margins, surface of valves with fine vertical striations and a pronounced knob in the center of each near the base. Preanal scale semicircular, with a slight median projection; lateral setiferous tubercules very small and removed from the margin.

Sternites smooth and completely glabrous, sternal area of metazonites raised between the legs into a platform much higher than level of prozonite (the new term "podosternum" is suggested with reference to this modification). Interzonal furrow sharply defined, its anteriormost portion partly overhung by the caudally reflected edge of the prozonite. Pleurites very finely granular, without other sculpture.

Legs relatively long and slender, the coxae without distal spines but those of prefemora long and sharp, distinctly curved caudad. Femora clavate, about as long as coxae and prefemora combined, postfemora short and thick, tibiae much longer and more slender, tarsi slender and gradually tapering, more than half as long as femora; tarsal claw nearly straight, slender, more than half the length of tarsus. Leg joints becoming increasingly setose distally, tip of tarsus set with numerous long macrosetae. Sternites of segments $4-6$ not produced or modified in any way. Sternal aperture of 7 th segment broadly oval, the entire caudal margin with a raised rim; anterior margin distinctly emarginate at the middle. 
Gonopods in situ directed cephalomesiad, their apices in contact and overlapping, extending forward between the legs of the 6th segment. Coxae rather small and subcylindrical, slightly shorter than telopodite, with small coxal apodemes and weakly developed coxal apophyses just above the origin of the solenite. Telopodite elongate and slender, of the form typical of the genus but with a rather small and slender secondary tibiotarsus which is only a little larger than the prefemoral process. Primary tibiotarsus short, only 58 percent of the

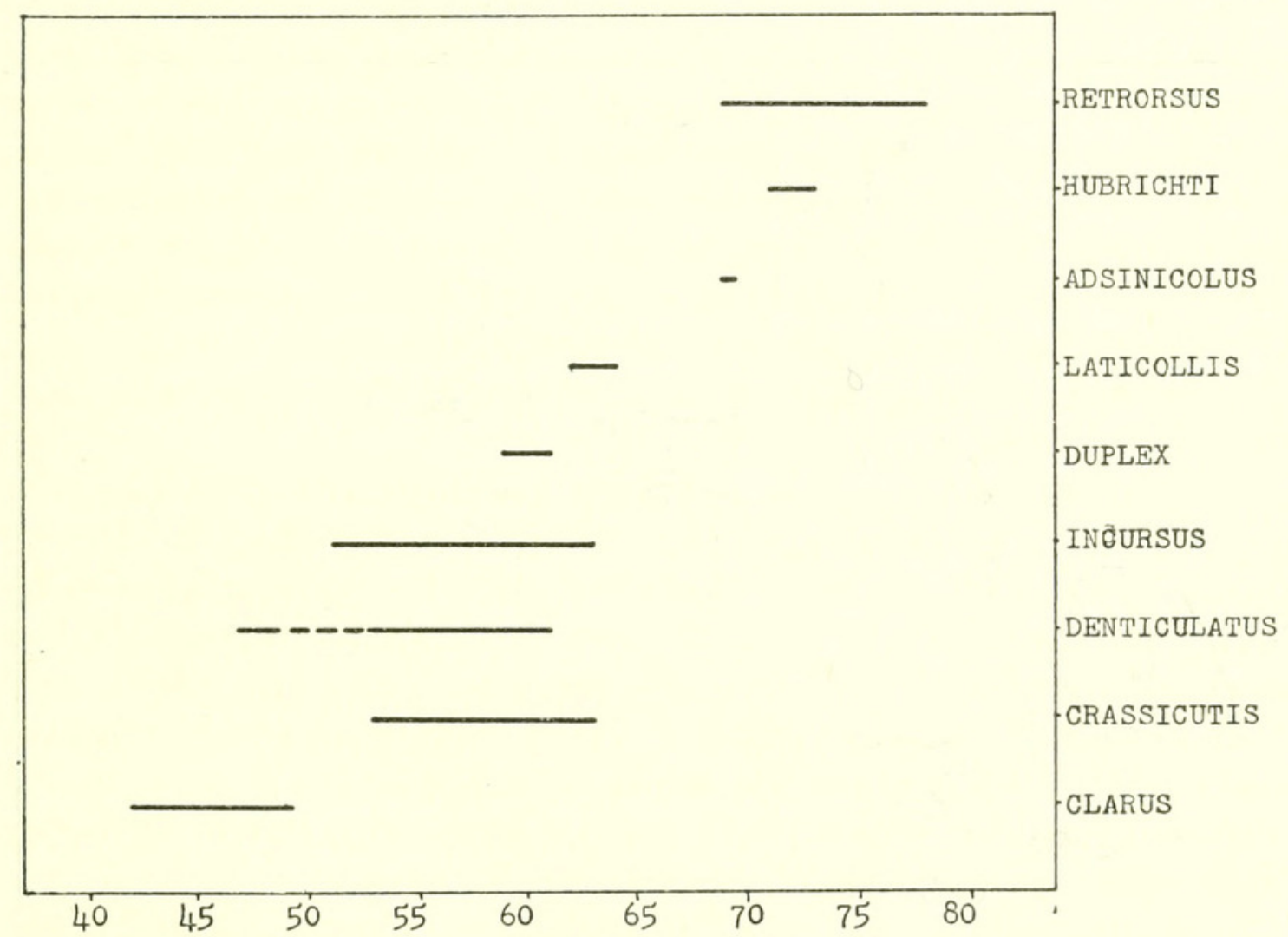

FigURE 2.-Graphic representation of variation in total length of the recognized forms of Pachydesmus, the horizontal scale divided into units of $5 \mathrm{~mm}$.

total length of the telopodite. Distal end of primary tibiotarsus slightly curved proximad of the terminal subdeltoid region (fig. 6).

Female: Similar in all external details of sculpture to the male, except for the more vaulted bodyform and slightly wider sternites. Cephaloventral edge of the $3 \mathrm{~d}$ segment on each side produced into a distinct rounded lobe. Cyphopods similar to those of the Pachydesmus crassicutis forms, the valves about equal in length to the receptacle.

Color: I have seen no living specimens of this species. According to the original description, "When in full color the dorsum is very dark, black or nearly so, with the carinae sharply contrasting by their lighter, in preserved specimens yellowish color ... Under surface and legs yellowish." Causey (op. cit.) notes that the color ". . . is 
as follows: dorsum black-brown, keels coral, venter and legs pale yellow."

VARIATION: The material I have examined is quite homogeneous in structure, there being no perceptible geographic variation. Ranges of from 42 to $49 \mathrm{~mm}$. in the length of mature specimens and from 8 to $10 \mathrm{~mm}$. in the width has been recorded. There is no sexual dimorphism in this respect.

Synonymy: Pachydesmus clarus was originally described without illustration of the gonopods, and it eventually fell into a sort of obscur-

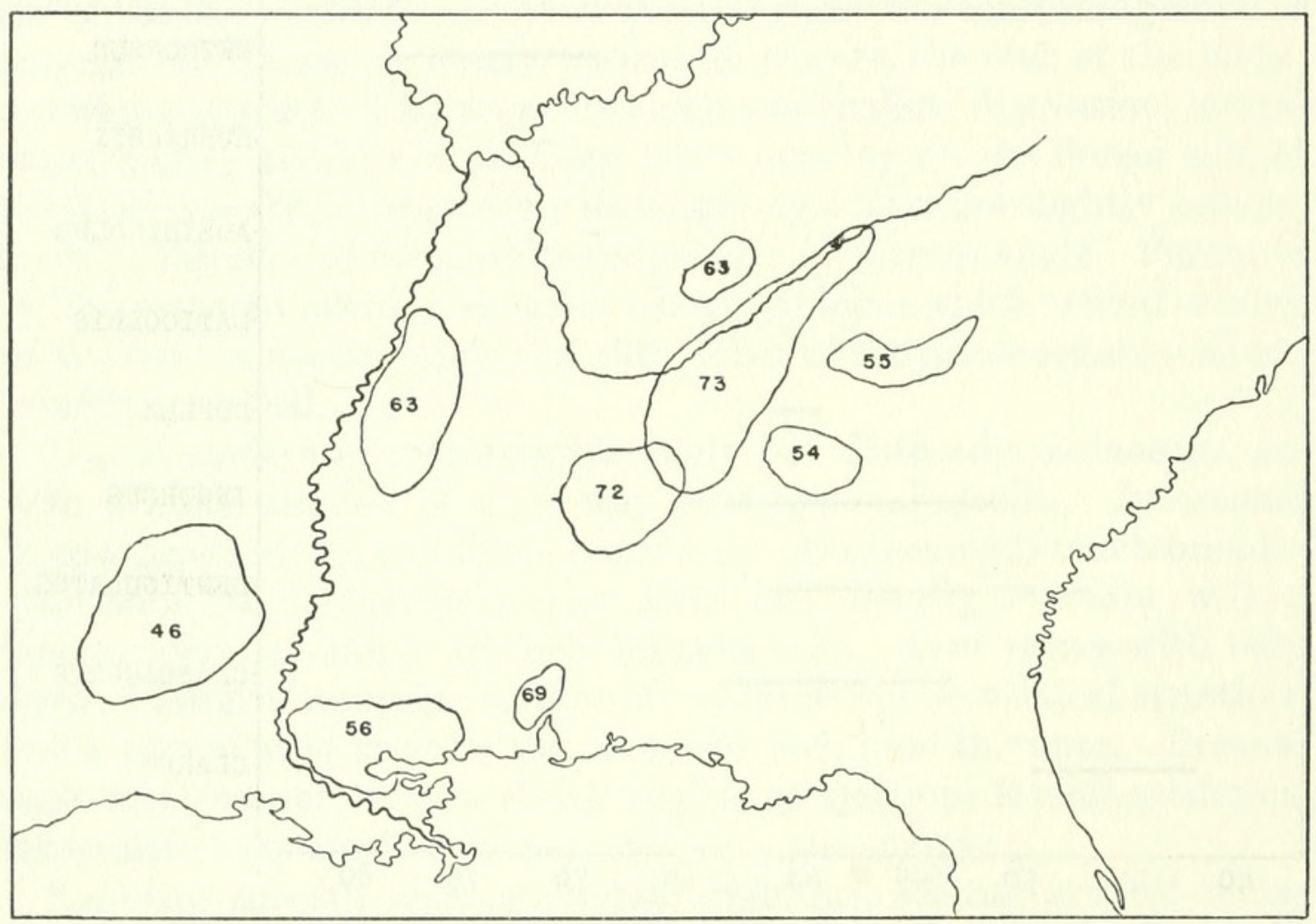

Figure 3.-Geographic variation of average length in nine populations of Pachydesmus. Known ranges are represented by the outlined areas; the enclosed figures indicate the average length of the specimens of that form measured.

ity owing to the difficulty of visualizing its generic attributes from a brief verbal description. The types were collected at Creston, Natchitoches Parish, in the upland hill region of western Louisiana, and were placed in the collection of the Museum of Comparative Zoology.

Twenty-two years after the description of clarus, Leslie Hubricht obtained a single male (virtually a topotype), at Kisatchi, also in Natchitoches Parish, La. This male was sent to Dr. Chamberlin and became the type of Pachydesmus kisaichinsis. Several years later, H. F. Loomis examined the material of clarus at Harvard and recognized its identity with kisatchinsis, the synonymy being recorded in a short note published in 1948 . 
Distribution: $P$. clarus, the only member of the genus known from west of the Mississippi River, is endemic to the upland parishes of western Louisiana above the Kisatchi escarpment. A single Texan locality is known, and it seems likely that the species will eventually be discovered in southern Arkansas. Material has been seen from the following localities:

Louisiana. Grant Parish: west of Pollock, $3 q q$, July 9, 1955, Leslie Hubricht (RLH); Dry Prong, 2 q , May 9, 1954, H. S. Dybas (CNHM). LaSalle Parish: Jena, $4 \sigma^{\top} \sigma^{7}, 5$ q 9 , Feb. 28, 1954, J. Stone (NBC). Lincoln Parish: Ruston, $1 \sigma^{\top}, 1$ q, Feb. 15, 1952, W. J. Harmon (NBC). Natchitoches Parish: Creston, $3 \sigma^{7} \sigma^{7}, 6$ ㅇ , Types, February-March 1915, K. P. Schmidt (MCZ, USNM) ; Bellwood, 1 ᄋ, Oct. 3, 1953, J. D. Montgomery (NBC) ; Chastine, 2 miles north of Creston, $1 \sigma^{\nearrow}, 3$ \% , Apr. 29, 1947, J. M. Schmidt (CNHM). Rapides Parish: Forest Hill, 2 우, Nov. 11, 1945, R. L. Wenzel (CNHM).

Texas. Newton County: Weirgate, 1 q, Mar. 28, 1943, Barth A. Maina (CNHM).

This species has also been recorded as Pachydesmus kisatchinsis, from Kisatchi, Natchitoches Parish, La. (1 $\sigma^{7}$, Mar. 29, 1937, Leslie Hubricht), by Chamberlin (1942).

\section{Pachydesmus crassicutis (Wood)}

Under this name I propose to associate all of the large pachydesmids known from the region east of the Mississippi River. In the past, each has been considered a full species, but the evidence of morphology and geographic distribution now available indicates that all of the valid forms represent only geographic races of a single widespread species. It has also become obvious, through direct comparison of the different forms, that the structural peculiarities upon which the names were based are much less real than apparent.

Although there seems to be a great difference between such forms as P. c. laticollis and P.c. incursus, other subspecies largely bridge the gap between them, and there is actually a geographic gradation to be observed in every character which might be considered diagnostic of a species.

No two forms of the crassicutis group occupy the same territory. Instead, the ranges are now known to be entirely complimentary, and one definite case of intergradation is known. Specimens taken between the ranges of $P$.c.laticollis and $P$.c.retrorsus are clearly intermediate as regards the structure of the gonopods.

Despite the general picture of geographic variability, I believe that most of the forms here considered valid will prove to be stable subspecific units. Except for minor, presumably individual variations, specimens taken through the extent of the range of a given subspecies are essentially alike, and there is no reason to believe that we are 
dealing with populations picked at random along an evenly grading geographic cline.

A recent attempt on the part of two entomologists to discredit and abolish the concept of subspecies seems to be founded upon the idea that every species is somewhat comparable to a normal spectrum, and that subspecies names represent only narrow strips of color chosen haphazardly and without consideration of intervening gradations of shade. But in those instances where populations of a species are

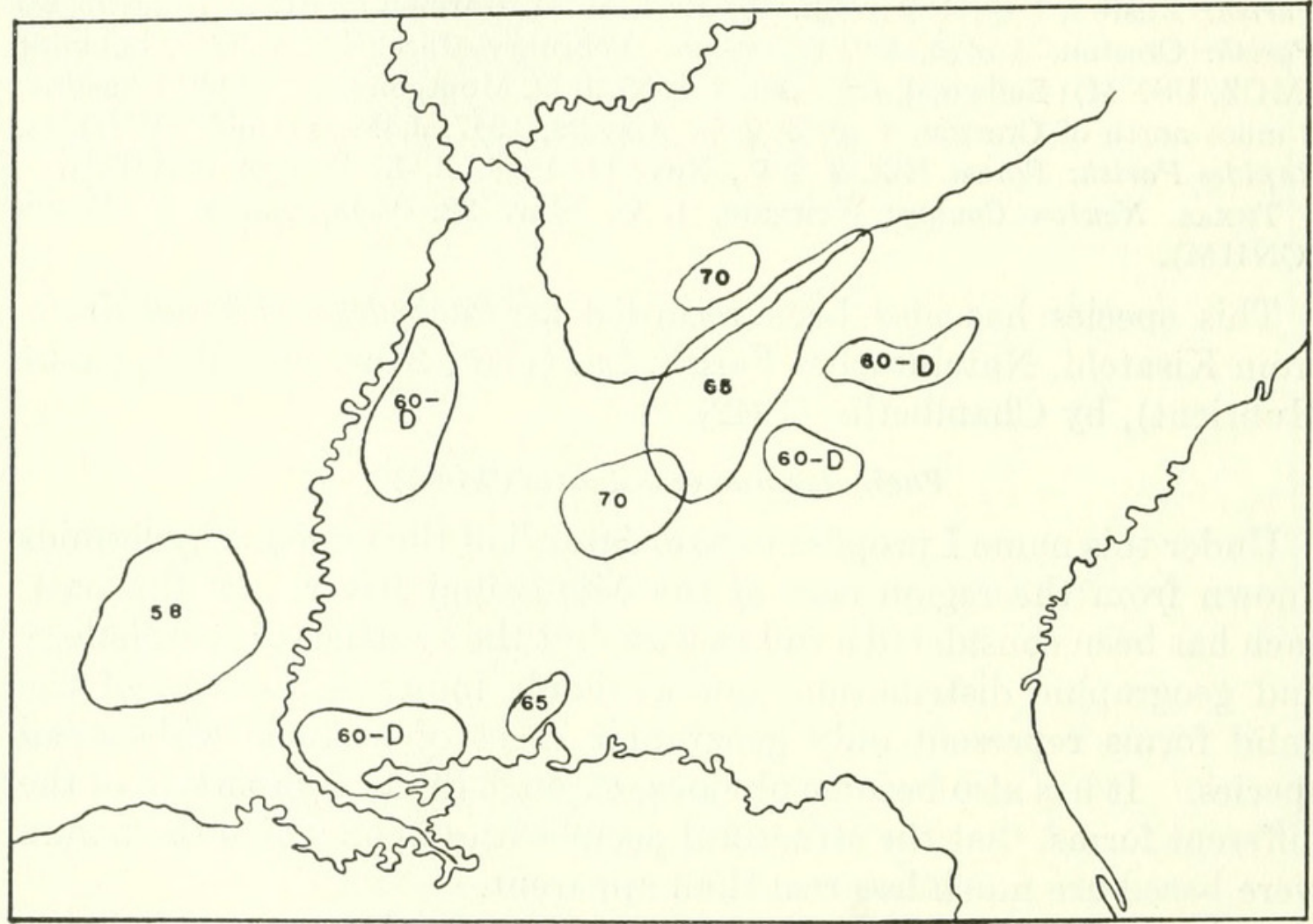

Figure 4.-Geographic variation in the gonopods in nine populations of Pachydesmus. Known ranges are represented by the outlined areas; the enclosed figures represent the length of the prefemoral region in terms of percentage of the total length of the telopodite. The letter "D" indicates that the leading edge of the primary tibiotarsus is denticulate or serrate.

known to maintain their characteristic features over a considerable area without particular intrapopulation variation, and tend to merge with adjoining populations where their ranges meet, I can not see how anyone can reasonably consider the naming of such infraspecific groups as superfluous and misleading. This seems the more true when it is recalled that the same critics of the Latin trinomial suggest replacing it by vernacular names alluding to the range of the population being considered.

Within the specific limits of Pachydesmus crassicutis, I recognize eight subspecies, separable chiefly on the basis of the gonopods, although supplementary correlated differences obtain in the size of 
the animals and, to a certain extent, their color pattern. Although these are all considered subspecies of a single form, two main groups of populations are easily recognizable, indicating that evolution has not been uniform throughout the range of the species. Near the
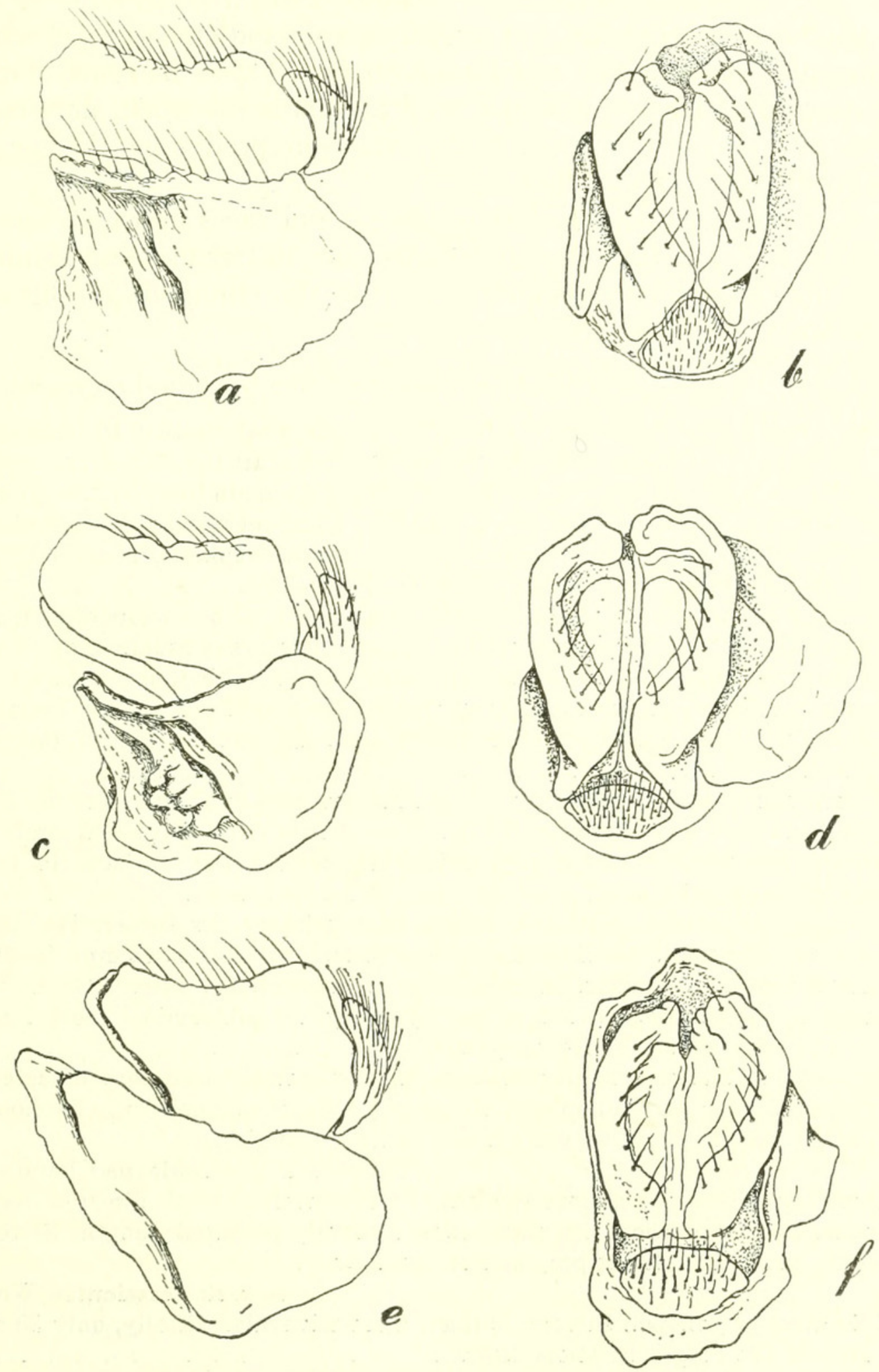

Figure 5.-Cyphopods of three subspecies of Pachydesmus crassicutis: $a, b$, distal and mesial aspects of $P$. c. laticollis; $c, d$, same, of $P$. c. hubrichti; $e, f$, same, of $P$. c. duplex. 
center of the range occurs a phratry of four closely related subspecies: laticollis, retrorsus, hubrichti, and adsinicolus. These are similar in their large size, testaceous color pattern, and in several particulars of the gonopods. Around the periphery occur four other subspecies: crassicutis, duplex, denticuiatus, and incursus, all of which are smaller, more colorful, and similar in gonopod structure, sharing, for instance, a serrated tibiotarsal blade. These marginal forms may be considered representatives of the ancestral stock, now more or less isolated by the centripetal evolution producing the larger, more specialized, interior forms.

It is interesting to note that in the several races of which female specimens are available, the cyphopods show differences and similarities in almost the same magnitude as do the gonopods of the corresponding males.

\section{Key to the subspecies of Pachydesmus crassicutis, based on males}

1. Prefemur of gonopod shorter, 60 percent or less the total length of the telopodite joint; mesial edge of tibiotarsal blade serrate or dentate (fig. 7, $a-d$ ); secondary tibiotarsus usually straight and subparallel to the main branch, its subterminal tooth generally much reduced or absent, if present usually directed distad, making the end of the process $\mathrm{Y}$-shaped; animals smaller, adult generally less than $65 \mathrm{~mm}$. in length (crassicutis phratry) . . . . . . . . . . . 2

Prefemur longer, 65-70 percent of the total length of the telopodite; mesial edge of tibiotarsal blade smooth; secondary tibiotarsus usually sinuate and divergent from the main branch, its subterminal tooth well developed and usually retrorse, directed proximad, making the end of the process T-shaped; animals larger, adults generally more than $65 \mathrm{~mm}$. in length (laticollis phratry) . . . . . . . . . . . . . . . . . 5 5

2. Subterminal tooth of secondary tibiotarsus completely absent; length, 59 to $61 \mathrm{~mm}$. (northern Mississippi) .. . . . . crassicutis duplex Chamberlin

Subterminal tooth of secondary tibiotarsus present but variable in form, occasionally quite small.

3. Secondary tibiotarsus distinctly longer than primary, its subterminal tooth reduced to a small subtriangular lobe or spur; length, 51 to $65 \mathrm{~mm}$. (western South Carolina, northern Georgia) . . . . crassicutis incursus Chamberlin

Secondary tibiotarsus not longer than primary, its subterminal tooth larger, in the form of a definite projection.

4. Secondary tibiotarsus slightly sinuous, its subterminal tooth perpendicular to the main axis; coxal apophysis elongated, distally rounded with the margin entire; length, 50 to $61 \mathrm{~mm}$. (north-central Georgia).

crassicutis denticulatus Chamberlin

Secondary tibiotarsus almost straight, its subterminal tooth directed distad; coxal apophysis short, its distal edge distinctly indented; length, 53 to 63 mm. (southern Mississippi, eastern Louisiana).

crassicutis crassicutis (Wood)

5. Tibiotarsus of gonopod shorter, bulkier, more triangular distally, only 30 percent of the length of telopodite . . . . . . . . . . . . . . . . . . 6

Tibiotarsus of gonopod longer, more slender, less enlarged distally, 35 percent of the length of telopodite. . . . . . . . . . . . . . . . . . 7 
6. Prefemoral process heavy, very thick in the region of its angulation, distally almost straight; subterminal tooth of secondary tibiotarsus smaller; coxal apophysis smaller; length, 55 to $64 \mathrm{~mm}$. (east-central Tennessee).

crassicutis laticollis (Attems)

Prefemoral process slender throughout, distally sinuate subterminal tooth of secondary tibiotarsus larger; coxal apophysis larger; length, 71 to $73 \mathrm{~mm}$. (central Alabame) . . . . . . . . crassicutis hubrichti, new subspecies

7. Tip of secondary tibiotarsus directed distad, the entire process nearly straight, broader, and strongly twisted at about the midlength; length, 69 to $70 \mathrm{~mm}$. (northern Aløbama, eastern Tennessee).

crassicutis retrorsus Chamberlin

Tip of secondary tibiotarsus directed proximad, the entire branch more slender and bisinuate, slightly twisted near its base; length, $69 \mathrm{~mm}$. (southern Alabama) . . . . . . . . crassicutis adsinicolus, new subspecies

\section{The crassicutis phratry ${ }^{2}$ \\ Pachydesmus crassicutis crassicutis (Wood)}

Figures $1, a, 7, a, 8, a, 9$

Polydesmus crassicutis Wood, 1864, p. 7; 1865, p. 224, fig. 55.

Pachydesmus crassicutis Cook, 1895, p. 5.-Pocock, 1909, p. 188.-Attems, 1938, p. 153, fig. 174 .

Fontaria crassicutis Brolemann, 1900, p. 101, pl. 6, figs. 28, 29.

?Fontaria louisiana Chamberlin, 1918a, p. 363 (Covington, La., type apparently lost).

Pachydesmus simulans Chamberlin, 1942, p. 4, figs. 9, 10 (Gonzales, Ascension Parish, La.; type in Chamberlin collection).

TyPe specimens: Wood's type series consisted of "numerous" specimens from Mississippi, and was borrowed from the Smithsonian Institution. No labeled material now appears to be extant, but in the U. S. National Museum collection are two very old fragmented specimens labeled only “E. Miss.," which may be remnants of the types. Unfortunately the gonopods are lost from both.

Diagnosis: A medium-sized pachydesmid (55-65 mm. in length) in which the leading edge of the primary tibiotarsus is serrate and the apices of the secondary tibiotarsus are unequal in length and directed divergently distad.

Description: Male specimen from Port Hudson, La.: length about $53 \mathrm{~mm}$., width, $11.5 \mathrm{~mm}$.

Front of head smooth and polished, evenly convex, with a small indistinct triangular flattened area between and below the antennal sockets. Genae large, extending slightly beyond edge of head capsule, each with a median impression. Vertigial groove distinct, ter-

\footnotetext{
3 The term "phratry" is here introduced (to the best of my knowledge for the first time) to designate a group of closely related subspecies which appear to form a natural group definable by several characters. Since most of the subspecies of $P$. crassicutis are quite similar in structural characters, it seems adequate to introduce extended descriptions only of a representative of each phratry.

The terms "group" and "section" appear to be more useful to designate assemblages of species below the level of, or in place of, the subgenus category.
} 
minating in a rather prominent rounded depression between the antennae. Two paramedian clypeal setae rather close to the labrum, and a pair of supra-antennal setae on each side of head. Antennae widely separated at base by a distance slightly less than length of $2 \mathrm{~d}$ antennal article. Antennae long, extending back to front of $3 \mathrm{~d}$ tergite; $2 \mathrm{~d}, 3 \mathrm{~d}$, and 6 th articles similar in size and shape, 4 th and 5th a little shorter. The 7 th article hemispherical, with four small terminal sensory cones. Antennae becoming increasingly setose distally, the first two articles almost glabrous.

Collum large, considerably wider than the following segment, its lateral ends strongly narrowed and bent cephalomesiad, entirely con-
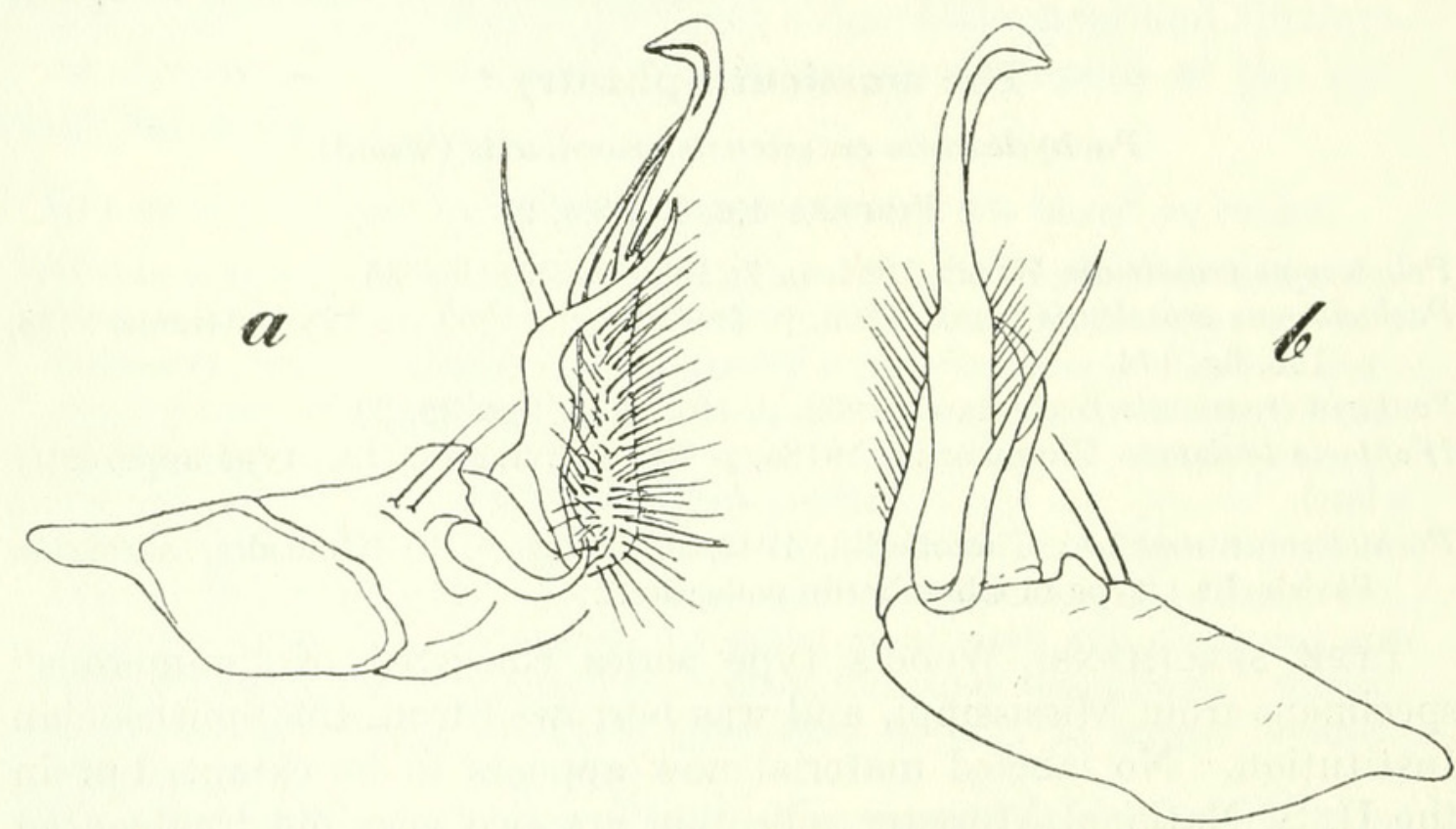

Figure 6.-Gonopods of Pachydesmus clarus: $a$, mesial, $b$, lateral aspect.

cealing base of mandibles when head is depressed. Surface of collum polished, not becoming coriaceous near the ends. Anterior edge straight, margined up as far as base of mandibles. Posterior edge straight across back, thence abruptly and sinuously swept forward.

Paranota of first eight segments directed forward, their corners broadly rounded, those of segments 9-15 transverse, those of last segments becoming increasingly produced caudad. Paranota narrow, less than one-third diameter of body cavity, subhorizontal but tilted cephaloventrad. Tergites of both prozonites and metazonites finely coriaceous, paranotal surfaces slightly more so. Peritreme swollen and polished, not set off by a groove. Anterior edges of paranota strongly margined, the posterior edges acute, not margined, those near the caudal end of body slightly convex, meeting caudal edge of metazonite at a slightly re-entrant angle. Interzonal furrow very distinct across dorsum and finely striate longitudinally. 
Paranota of 18 th segment forming acute subtriangular lobes, those of 19 th bluntly rounded and very slightly convergent. Telson short, granular, with evenly converging sides and a distinct setiferous knob near the base on each side. Anal valves moderately convex, with a small swelling near the base of each, the mesial margins with strongly compressed edges. Preanal scale large, about twice as wide
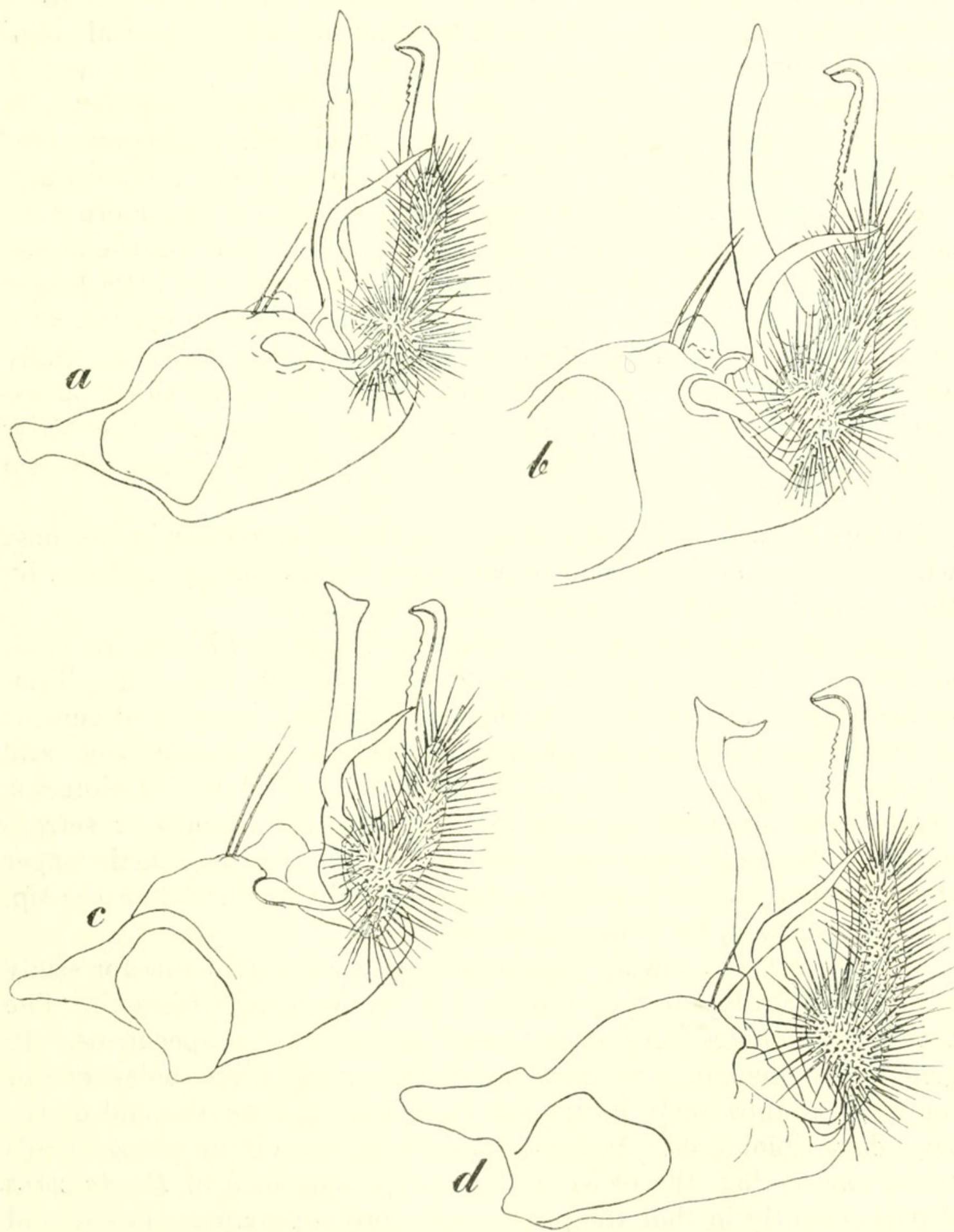

Figure 7.-Mesial aspect of male gonopods of Pachydesmus: a, P. crassicutis crassicutis from Port Hudson, La.; b, P. c. duplex from Grenada, Miss.; c, P.c. incursus from Easley, S. C.; d, P.c. denticulatus from Atlanta, Ga. 
as long, the caudal edge evenly curved, the setiferous tubercules small and set back from the edge.

Sternites smooth and glabrous, sternal area of metazonites raised between legs into a platform higher than level of prozonites, segments 8-10 each with a distinct cruciform impression, segments 11-16 with a large transverse knob between the second legpair. Interzonal furrow broad and well defined on sides, curving in front of spiracles, and reduced to a narrow suture across sternal area. Spiracular opening large and reniform, its edges low and rounded. Pleural areas finely granular, those of midbody segments swollen and more tuberculate just above the legs. Caudal edge of metazonites margined down the sides. Prozonites smooth and polished ventrally.

Legs massive, the coxae without distal armature, prefemora with short but acute distal spines and a characteristic knob on the dorsal side. Femora robust, about twice as long as thick and little longer than the other leg joints. Tarsal claw long and slightly curved, with several very fine parallel ridges on the dorsal side. Legs, especially anterior pairs, covered on the ventral sides with very thick pubescence, the dorsal surfaces almost glabrous. Sternites of anterior segments without modification except for very low knobs between the 4th legpair.

Gonopod aperture broadly transverse, about twice as wide as long, with a raised margin in front of each coxite and caudally bounded by the elevated sternal area between the 7 th legpair.

Coxae of gonopods heavy and subyclindrical, with short coxal apodemes. Coxal apophysis small and distally indented. Telopodite about same length as coxa, its prefemoral division 60 percent of length, and densely setose, prefemoral process rather long and slender, evenly curved instead of medially geniculate. Tibiotarsus slender and laminate, the leading edge finely fimbriate or serrate distally. Secondary tibiotarsus slender, nearly straight, a little longer than primary, its subterminal process normally smaller than the tip, and oblique to it, both distally divergent.

VARIATION: The few specimens that have been available for study afford practically nothing tangible in the way of variation. The total length ranges from 53 to $62 \mathrm{~mm}$. in three intact specimens. In general the gonopods are remarkably alike in all three males, except for what is apparently individual variation affecting the end of the secondary tibiotarsus. As shown in figure 9, one of the prongs tends to be longer than the other, but the type specimen of $P$. simulans departs slightly in that the prongs are more approximate in size and length. Aside from this, the remainder of the gonopod and the rest of the animal is so similar to the other specimens of crassicutis that simulans can scarcely be maintained as a distinct entity. The speci- 
men came from a locality directly between those from which the other two illustrated millipeds originated.

Synonymy: Of the early references to crassicutis, only those of Wood and Brolemann seem to apply to the typical subspecies. The latter author described and illustrated material from Louisiana, and his account was abridged by Attems (1938) for his treatment of the species.
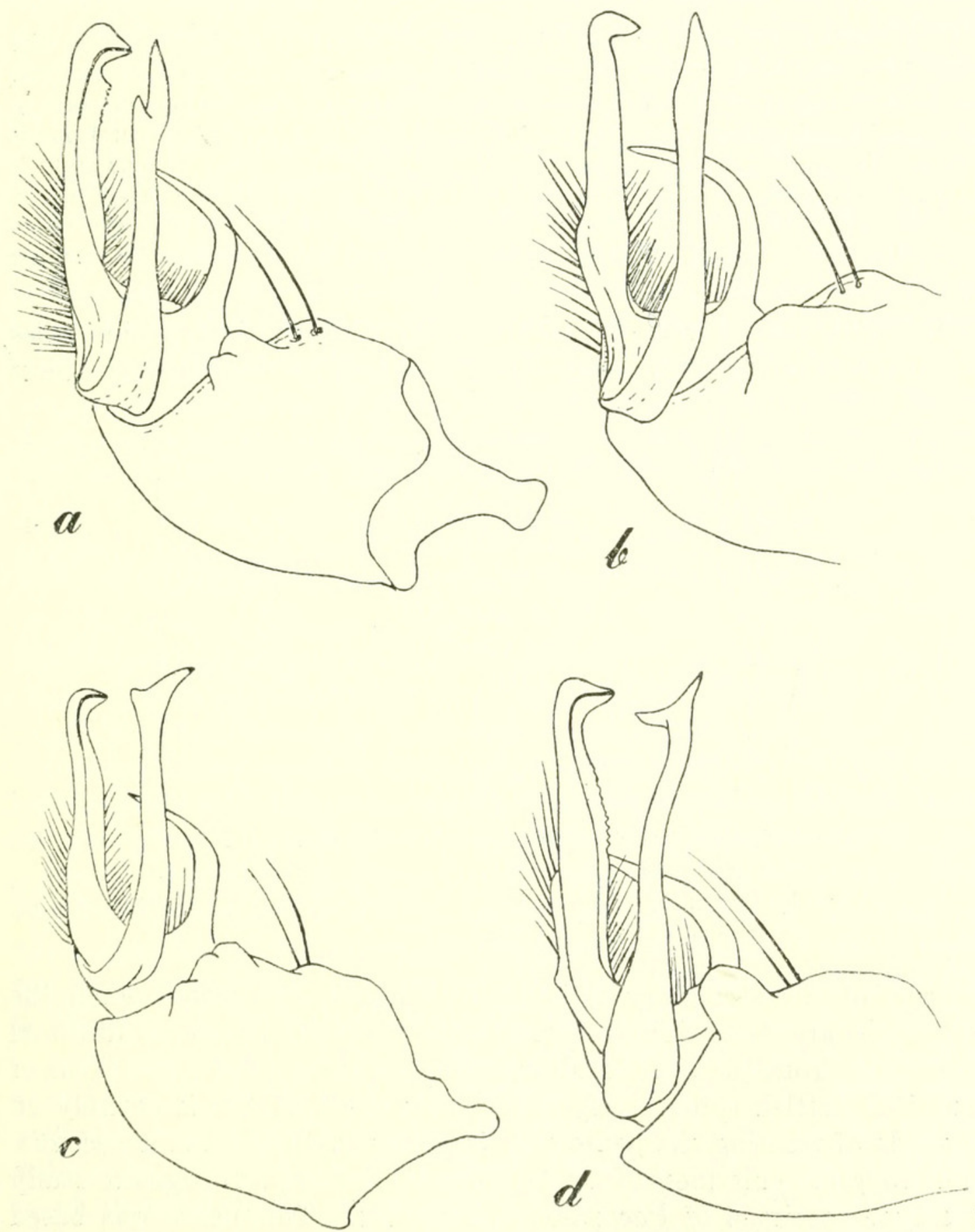

Figure 8.-Lateral aspects of male gonopods of Pachydesmus, the same specimens depicted in figure 7: $a, P$. crassicutis crassicutis; $b, P . c$. duplex; $c, P . c$. incursus; $d, P$. c. denticulatus. 
Fontaria louisiana Chamberlin is included as a doubtful junior synonym partly on the basis of its type locality and partly because there is nothing in the original description to preclude such an association. The name was proposed without diagnosis, comparison to any other species, or illustration, and, to make matters worse, I have been unable on two occasions to locate the type at the Museum of Comparative Zoology. The description of the gonopods of louisiana is quoted in full:

Characterized by the structure of the gonopods of the male. In these the posterior or principal limb of the telopodite is bifid, the branches long, slender, and subequal and cross those of the other gonopod; of the two branches of prongs the mesal one is geniculate near tip with the latter acute, while the ectal one is straight, its tip also acute. The proximal, undivided and less chitinous stalk is thick, densely hairy, and is prolonged along the mesal side of the mesal prong. The anterior or lesser spine is much shorter than the bifid branch, it is much narrowed distad, is moderately sigmoidally flexed, and crosses that of the other gonopod.

According to this verbal characterization, both tibiotarsal branches are distally simple. I find, however, that in crassicutis the subapical
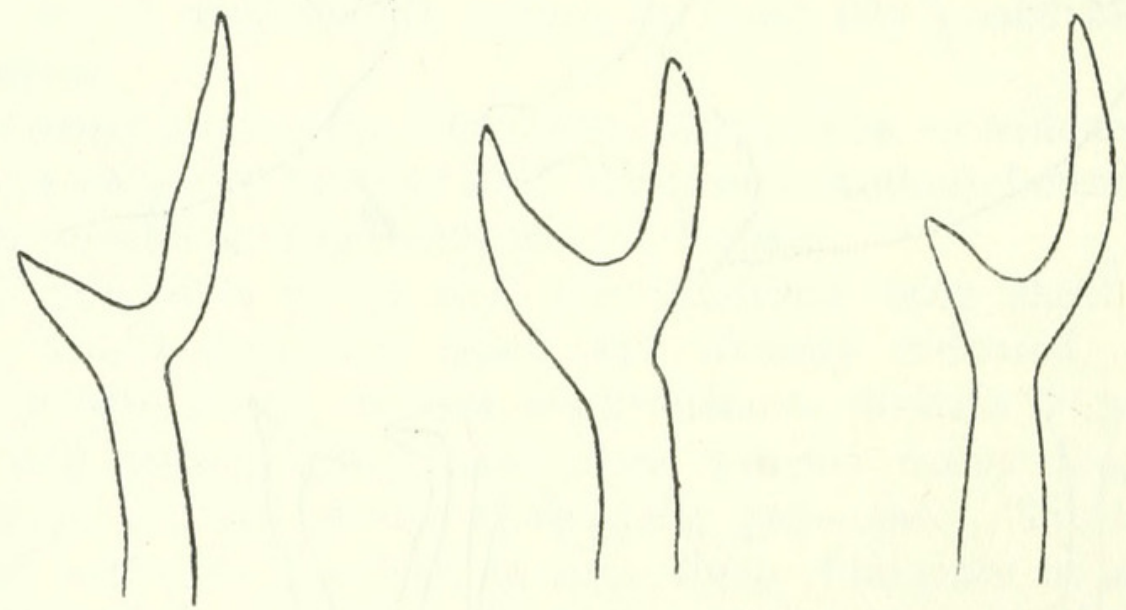

FIGURE 9.-Distal end of the secondary tibiotarsus of three specimens of Pachydesmus crassicutis crassiculis from Louisiana. Left to right: from Port Hudson, East Baton Rouge Parish; Gonzales, Ascension Parish; and New Orleans Parish.

process of the secondary tibiotarsus is usually concealed when the gonopods are viewed in place. Until the holotype, or additional specimens from the type locality, can be examined and the status of louisiana settled conclusively, I feel that the evidence is entirely on the side of treating the name as a junior syonym of $P$. c. crassicutis.

Through the kindness of Dr. Chamberlin, I was priviledged to study the type specimen of Pachydesmus simulans. This name was based upon a male from the vicinity of Gonzales, Ascension Parish, La., a locality bracketed by the known localities for crassicutis. Chamberlin's (1942) original description stated that simulans is-- 
A species apparently very close to $P$. retrorsus, known from Knox County, Tennessee. It seems distinct, however, in the details of the gonopods, although these are of the same type. The two branches are more slender, and relatively longer and closer together. The distal prongs of the outer branch form an acute angle with each other instead of a very obtuse one or a semicircle, and the bent portion at end of inner branch is shorter.

The differences stipulated above are quite valid ones to distinguish simulans from retrorsus, but no consideration was made, apparently, of the pachydesmid previously known from southern Louisiana. The three specimens I have seen from that area are all identical in gonopod structure except for a slight variation affecting the secondary tibiotarsus in the type specimen of simulans (figure 9). This difference, probably only an individual variation, is hardly of sufficient magnitude to warrant recognition of simulans as a valid name.

Distribution: Insofar as presently known, $P$. c. crassicutis is restricted to the Gulf Coastal Plain in the vicinity of the Mississippi Delta country. There are no definite localities known for Mississippi, although the form certainly must occur there. Material has been seen from the following localities:

Louisiana. East Baton Rouge Parish: Port Hudson, $1 \sigma^{7}$, Dr. Leavitt (MCZ) • Ascension Parish: 4 miles north of Gonzales, 1 б', Aug. 31, 1940, Stanley and Dorothea Mulaik (RVC). Orleans Parish: New Orleans, $1 \sigma^{\top}$, H. E. Hubert (MCZ).

Mississippı. "E. Miss." with no further data, $2 \sigma^{7} \sigma^{7}$ (USNM).

\section{Pachydesmus crassicutis denticulatus Chamberlin}

Figures $7, d, 8, d$.

Fontaria crassicutis Bollman, 1888, p. 344.

Pachydesmus denticulatus Chamberlin, 1946, p. 152, figs. 8, 9.-Chamberlin and Hoffman, 1958, p. 43.

Type specimens: Male holotype, female allotype, and two male paratypes (RVC); from the vicinity of Atlanta, Ga., collected at intervals between 1939 to 1943 by the late Prof. Perry W. Fattig.

Diagnosis: A medium-sized subspecies of the crassicutis phratry characterized primarily by the slender, sinuous secondary tibiotarsus, which terminates in two equal-sized processes, and by the simple, rather elongated coxal apophysis. The color in life is not known, but is probably brown with yellow paranotal maculae.

VARIATION: I have seen but a single specimen definitely referable to this form, the paratype kindly loaned for study by Dr. Chamberlin. The gonopods of this milliped appear to be identical in every respect with those figured in the original description. The length of $47 \mathrm{~mm}$. cited for the holotype seems somewhat short in relation to the width of $12.5 \mathrm{~mm}$., suggesting that perhaps the caudalmost segments are telescoped. The paratype examined measures $61 \mathrm{~mm}$. in length and $13 \mathrm{~mm}$. in width. The specimen recorded from Indian Springs, Ga., 
by Bollman (1888) measures $70 \mathrm{~mm}$. in length and $15 \mathrm{~mm}$. in width.

Distribution: $P$. c. denticulatus is known only from the Piedmont region of north-central Georgia. Aside from the type locality, the only known station is Indian Springs, Bibb County, Ga., where a single male was collected by Prof. Lucien M. Underwood. Unfortunately the gonopods of this individual were removed and lost at some time in the past, making a conclusive determination impossible. However, considering the proximity of Indian Springs to Atlanta, and the similarity of size and structure in specimens from the two places. I think that my allocation will eventually be verified by collections made in the region concerned.

\section{Pachydesmus crassicutis duplex Chamberlin}

Figures $1, d, 5, \mathrm{e}, f, 7, b, 8, b$,

Pachydesmus duplex Chamberlin, 1939, p. 5, fig. 8.-Chamberlin and Hoffman, 1958, p. 43.

Type specimen: Male holotype (RVC), from Grenada, Grenada County, Miss., collected in July 1910 by Dr. Chamberlin.

Diagnosis: A medium-sized member of the crassicutis phratry, characterized by the long, slender, simple secondary tibiotarsus, which completely lacks any remnant of the subapical process and which equals or slightly exceeds the primary branch in length. The cyphopods are distinct from those of members of the laticollis phratry in that the receptacle is roughly triangular in mesial aspect, its distal end acuminate and considerably exceeding the ends of the valves. In life the color is dilute black, with clear yellow paranotal maculae.

Variation: Four adult specimens studied showed the normal range of variation in size. The largest is the male holotype, with a length of $72 \mathrm{~mm}$. and a width of $15 \mathrm{~mm}$. The other three specimens, a male and two females, measure 61 and $59 \mathrm{~mm}$. in length, respectively. The male, from Memphis, Tenn., differs slightly from the holotype in that the secondary tibiotarsus is slightly sinuous instead of nearly straight, but this can at present be considered little more than within the normal range of variability.

Distribution: P. c. duplex appears to be endemic to the upper half of the Cretaceous embayment region in northern Mississippi and western Tennessee. It seems probable that collecting in the future will reveal the presence of the subspecies in the western tip of Kentucky. Specimens have been examined as follows:

Mississippi. Grenada County: Grenada, 1 क (holotype), July 1910, R. V. Chamberlin (RVC). Marshall County: Holly Springs, 1 \&, Sept. 17, 1955, L. Hubricht (RLH). 
Tennessee. Shelby County: Overton Park, Memphis, $\sigma^{\top 7}$ and $\subsetneq$, Oct. 1, 1955, Hubricht (RLH).

\section{Pachydesmus crassicutis incursus Chamberlin}

Figures $7, c, 8, c$

Pachydesmus incursus Chamberlin, 1939, p. 5, fig. 7.-Chamberlin and Hoffman, 1958 , p. 43.

Pachydesmus retrorsus (not of Chamberlin 1921) Hoffman, in Wray, 1950, p. 44 (misidentification).

Type specimen: Male holotype (RVC) from Taylors, Greeneville County, S. C., collected Aug. 3, 1910, by Dr. Chamberlin.

Diagnosis: a moderate to large member of the crassicutis phratry characterized particularly by the shape of the secondary tibiotarsus of the gonopod, in which the subapical process is reduced to a rather small marginal spur, and the main termination somewhat exceeds the tip of the primary tibiotarsus. The leading edge of the latter is finely denticulate as in the three other members of the phratry, and the coxal apophysis is low and bilobed or trilobed. Paranotal markings apparently pinkish in life.

Variation: A range in body length of from 51 to $63 \mathrm{~mm}$. has been noted, the width varying from 10 to $13.5 \mathrm{~mm}$. The gonopods of the three males at hand exactly match each other and the original illustration given for this form, except that in one, possibly only aberrant, the subapical process of the secondary tibiotarsus is enlarged at the expense of the terminal tip, so that the effect is a complete reversal of the appearance here figured as typical for the race.

The original description states that the paranota of the living animal are yellow. The specimen from Easley, S. C. (not far from the type locality), is accompanied by a label indicating that in life the specimen was "grayish brown with pinkish carinae." It will certainly be of interest to learn the living colors of material of incursus obtained in the future.

Distribution: This form, the easternmost representative of the genus, seems to be an upcountry and foothill milliped, as the known collection stations are in or closely adjacent to the southeastern end of the Blue Ridge range. I have examined three male specimens from the following localities:

South Carolina. Pickens County: Easley, $1 \sigma^{7}$, November 1913, C. S. Marshall (USNM).

Georgia. Habersham County: Tallulah Falls, $1 \sigma^{7}$, August 1887, Lucien M. Underwood (USNM).

North Carolina. "Mtns. of N. C.," $1 \sigma^{\text {r }}$, without date, Roland Thaxter (USNM). This locality is probably either near Tryon, in Polk County, or in Macon County between Franklin and Clayton, Ga. 


\section{The laticollis phratry}

\section{Pachydesmus crassicutis laticollis (Attems)}

Figures $5, a, b, 10, d, 11, d$

Fontaria laticollis Attems, 1899, p. 258, pl. 13, fig. 312.

Pachydesmus laticollis Pocock, 1909, p. 189.-Attems, 1938, p. 154, fig. 176.Chamberlin and Hoffman, 1958, p. 44.

Pachydesmus retrorsus Loomis, 1943, p. 403.

Type specimen: Male, in the Berlin Museum, labeled only "Illinois."

Diagnosis: A medium-sized subspecies of the laticollis group, in which the tibiotarsus is only 30 percent of the telopodite length, with a small angulation on its leading edge; prefemoral process conspicuously thickened at the geniculation and nearly straight in its distal half; secondary tibiotarsus long, slender, and sinuous, with both its tip and subterminal process slightly recurved proximad. The distal margin of the receptacle of the cyphopod is straighter than in females of other known forms, and the valves longer in proportion to their height. Color in life medium to dark brown, with yellowish or testaceous paranota.

VARIATION: Despite the fairly large range occupied by this form, there is no perceptible variation in gonopod structure or in other details of body form. In the material studied the length varied from 62 to $70 \mathrm{~mm}$., width from 12 to $14 \mathrm{~mm}$. There is apparently some geographic variation in size, with a decrease from south to north. Specimens from the Tennessee River valley, in Marion County, Tenn., and Jackson County, Ala., range from 66 to $70 \mathrm{~mm}$. in length; those from the Cumberland Plateau of central Tennessee from 62 to $65 \mathrm{~mm}$. Attems' type specimen is stated to be only $55 \mathrm{~mm}$. long and $10 \mathrm{~mm}$. wide, considerably smaller than any I have examined.

Remarks: Fortunately, although Attems' original drawing of the gonopod of laticollis is made from low magnification and a difficult aspect, the characters peculiar to the subspecies are clearly shown. It is to be regretted that nothing is known of the history of the type specimen, for it seems unusual that a scarce milliped from a relatively remote area such as central Tennessee would find its way to the Berlin Museum. The specimen, according to Attems, was originally labeled "Fontaria virginiensis," although by whom is unknown.

Distribution: This subspecies is known to occur from Jackson County, Ala., north to Cumberland County, Tenn., chiefly through the Cumberland Mountain Range but also to the west of it in the Highland Rim area of central Tennessee. Presumably the great bend of the Tennessee River marks the southern limits of the range. Specimens have been examined from the following localities:

Tennessee: Cumberland County: Grassy Cove, 12 miles southeast of Crossville, $1 \sigma^{7}$, Sept. 15, 1957, P. C. Holt (RLH). White County: Sparta, $1 \sigma^{\nwarrow}$, July 15, 
1933, W. J. Gertsch (AMNH); 2 miles west of Bon Air, $1 \sigma^{\top}$, May 9, 1951, L. Hubricht (RLH). Warren County: McMinnville, 1 q, May 9, 1951, L. Hubricht (RLH). Marion County: west fork of Pryor Cove, 2 miles northeast of Jasper, 2 ఠ $\sigma^{7}$, June 27, 1957, L. Hubricht (RLH). Coffee County: 4 miles southeast of Manchester, 1 ơ June 26, 1957, L. Hubricht (RLH).

Alabama. Jackson County: Russell Cave, $1 \sigma^{7}$, May-August 1957, Carl F. Miller (USN M); near Blowing Cave, 5 miles southeast of Limrock, $1 \sigma^{\nwarrow}$, June 19. 1957, L. Hubricht (RLH).

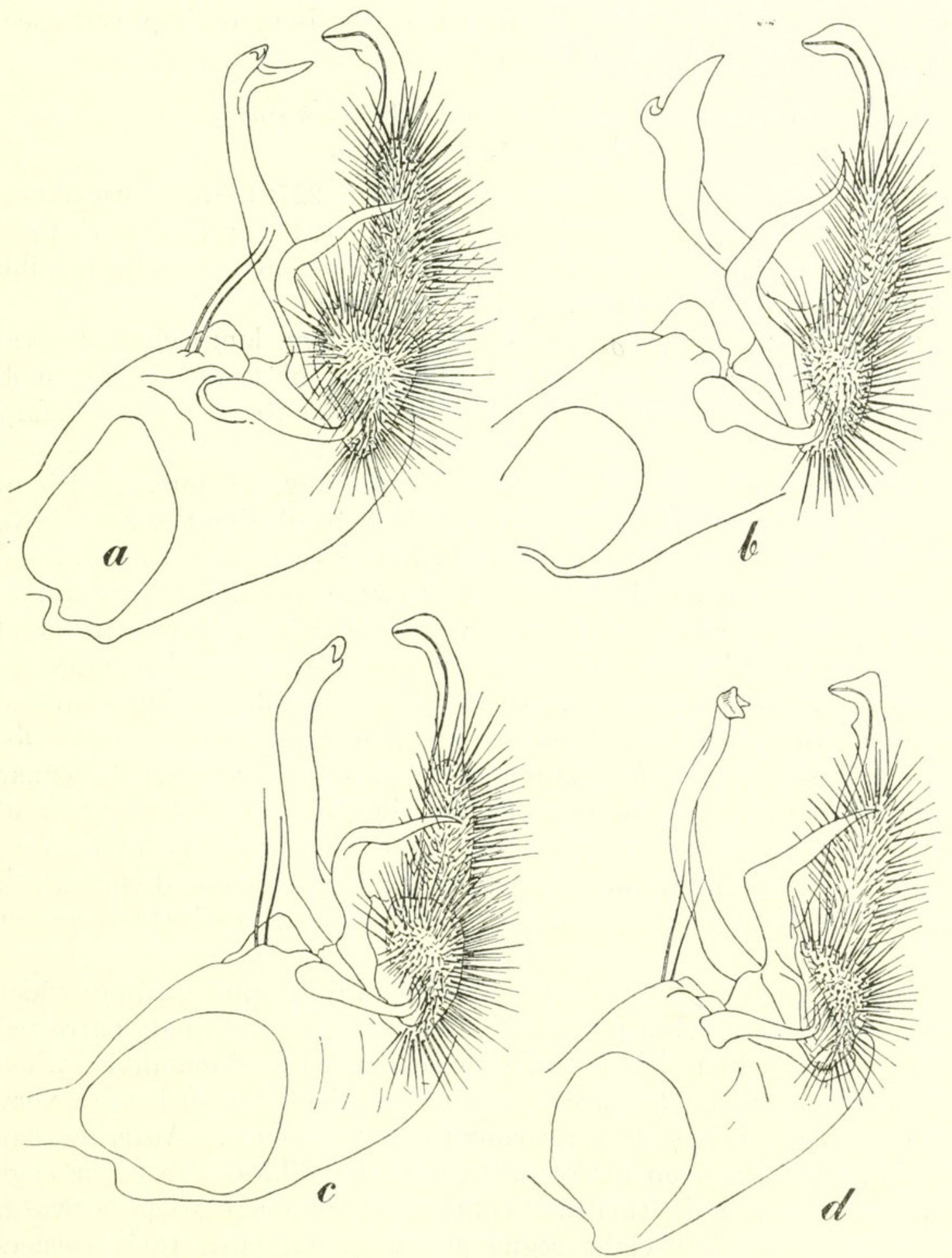

Figure 10.-Mesial aspects of the left male gonopods of Pachydesmus: a, P. crassicutis hubrichti from Tuscaloosa, Ala.; b, P. c. retrorsus from Knox County, Tenn.; c, P. c. adsinicolus from Mobile, Ala.; d, P. c. laticollis from Sparta, Tenn. 
The Tennessee specimens agree closely with the subspecies as defined by the drawings. Those from Alabama, however, tend to approach $P$. c. retrorsus both in size and gonopod characters, and the specimen taken by Hubricht near Limrock is so thoroughly intermediate in characters that it might easily be considered closer to retrorsus than to laticollis. It seems probable that the specimens reported (Loomis, 1943) as retrorsus from Madison County, Ala., are actually referable to laticollis on the basis of their provenance, somewhat west of Jackson County.

\section{Pachydesmus crassicutis hubrichti, new subspecies}

Figures 5,c,d, 10, $a, 11, a$

Type specimens: Male holotype (USNM 2272) from Tuscaloosa, Tuscaloosa County, Ala., collected Mar. 30, 1948, by George E. Ball; two female paratypes (USNM 2272) collected at Woodstock, Bibb County, Ala., May 4, 1953, by Leslie Hubricht.

Diagnosis: A large form (more than $70 \mathrm{~mm}$. long) characterized by the short, distally subdeltoid tibiotarsus of the male gonopod, as well as by the very large subterminal tooth of the secondary tibiotarsus.

Description of HOLOTYPe: Length of body, $71 \mathrm{~mm}$., width of midbody segment, $15.5 \mathrm{~mm}$. Segments $4-16$ of about equal width.

Front of head smooth and polished, evenly convex except for a distinct subtriangular flattened clypeal area. Genae large, extending well beyond lateral edge of head capsule, each with a prominent broad median impression. Vertigial groove distinct, becoming more so anteriorly, terminating in a small bipunctate depression centered between the antennae. Two paramedian frontal setae, two subantennal setae, and four supra-antennal setae present. Antennae widely separated at base by a distance slightly greater than length of $2 \mathrm{~d}$ antennal article. Antennae long, extending back to middle of $3 \mathrm{~d}$ tergite. The $2 \mathrm{~d}, 3 \mathrm{~d}$, and 6 th articles similar in size and shape, 4 th and 5th slightly shorter. The 7 th article hemispherical, with four sensory cones.

Collum large, $5.0 \mathrm{~mm}$. long at middorsal line, almost $2 \mathrm{~mm}$. wider on each side than following tergite, the lateral ends strongly narrowed and bent cephalomesiad, entirely concealing base of mandibles when head is depressed. Surface of collum polished, the disk with very fine scratches, becoming coriaceous toward the ends. Anterior edge straight, margined up as far as base of mandibles. Posterior edge straight across back, thence abruptly and sinuously swept forward.

Paranota of first eight segments swept forward, their corners broadly rounded, those of segments 8-15 transverse, those of last segments becoming increasingly produced caudad. Paranota narrow, 

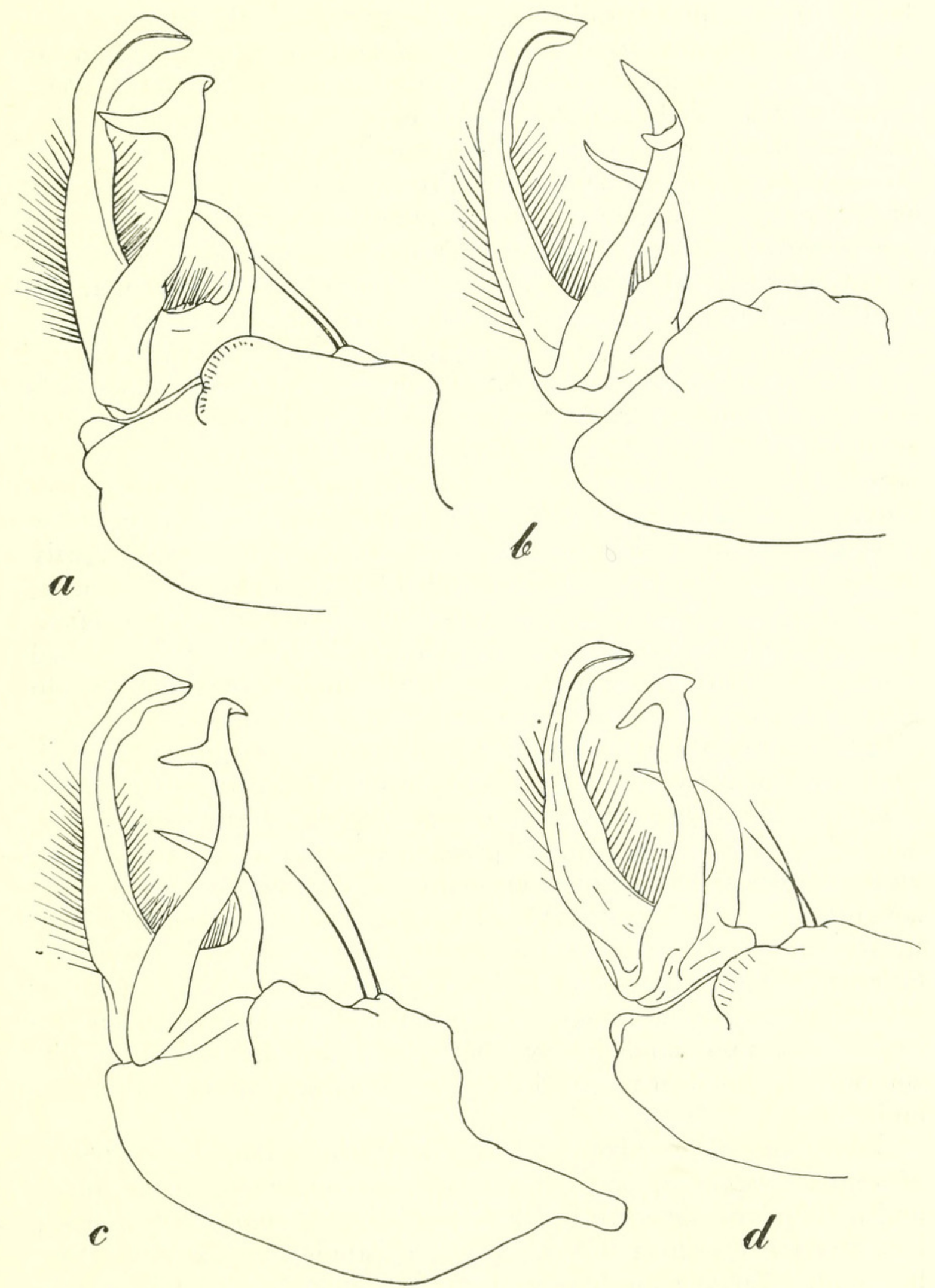

Figure 11.-Lateral aspects of left male gonopods of Pachydesmus, from the same specimens depicted in figure 10: a, P. crassicutis hubrichti; b, P. c. retrorsus; c, P. c. adsinicolus; d, P. c. laticollis. 
less than one-third the diameter of body cavity, almost horizontal but tilted cephaloventrad. Tergites of both prozonites and metazonites finely coriaceous, becoming more so on the paranota. Peritremata swollen and polished, but not set off by a submarginal groove, their surfaces thus continuous with rest of paranota except in texture. Anterior edges of paranota set off by a deep marginal groove, the posterior edges acute, not margined, and on the caudalmost segments are convex, meeting the caudal edge of the metatergite at a slight re-entrant angle. Interzonal furrow very distinct across dorsum, and finely costulate.

Paranota of 18th segment forming acute subtriangular lobes, those of 19th more broadly rounded. Telson short, finely granular, its sides evenly converging, the median process distally truncate with the terminal setae set in a small median impression. No distinct setiferous knobs near the base of telson on each side. Anal valves moderately convex, vertically striate, with a small swelling near the base of each, the mesial margins with strongly compressed, obliquely striate edges. Preanal scale large, about half as long as broad, its caudal edge evenly curved without distinct median projection. Lateral setiferous tubercules very small and indistinct, well removed from edge. Anterior edge of preanal scale slightly overlapping onto caudal edge of the preceding segment.

Sternites smooth and completely glabrous, sternal areas of metazonites raised between legs into a platform, the podosternum, which is appreciably higher than level of prozonite, those of segments 8-10 each with a distinct cruciform impression and those of segments 11-16 with a large transverse knob between the caudal pair of legs. Interzonal furrow broad and sharply defined down sides, curving forward in front of spiracles, but reduced to a mere suture across the venter. Spiracular opening large and auriculate, with raised and flared edges. Pleural areas finely granular, those of midbody segments swollen and more tuberculate immediately above legs. Caudal edge of metazonite with a distinct raised rim down the sides. Prozonites smooth and polished.

Legs stout and massive but rather long, the coxae without traces of ventral armature, prefemora with short but acute distal spines and a characteristic knob on the dorsal side. Femora very robust, less than twice as long as thick and but little longer than any other leg joint. Tarsal claw long and slightly curved, with four to six distinct parallel ridges on its dorsal side. Legs covered on the ventral side with very thick short pubescence, dorsal sides, except of tarsal joints, almost glabrous. Sternites of anterior segments without knobs.

Gonopod aperture very broadly transverse, about $2 \frac{1}{2}$ times as wide as long, laterally with a short raised rim in front of each coxite, and 
caudally bordered by the greatly elevated sternal area of the 7 th legpair.

Coxae of gonopods rather massive, somewhat longer than the telopodites, the coxal apophysis large but not elevated, its margin nearly smooth. Prefemur of telopodite large, 70 percent of the length, densely setose, prefemoral process slender and bisinuate, poorly sclerotized. Tibiotarsus short and stout, constricted at its midlength, distally expanded and subdeltoid. Secondary tibiotarsus shorter than primary, nearly straight, terminally directed mesiad and slightly hooked, the subterminal process large, perpendicular to the main axis, and directed laterad.

Female: Similar to the male in external structure, aside from a slightly more arched dorsum. The pleural lobes of the $3 \mathrm{~d}$ segment are very pronounced and conspicuous. Cyphopods large, the valves in lateral aspect being nearly as large as the mesial face of the receptacle. Latter strongly concave on its inner distal surface, and provided there with a small cluster of prominent rounded tubercules and rugosities. Inner valve slightly shorter than outer.

Color: The color in life is not known, but recently preserved specimens are light brown or tan, with the caudolateral halves of the paranota dilute yellow.

VARIATION: The three known specimens, a male and two females, measure 71,72 , and $73 \mathrm{~mm}$. in length, respectively. The male appears to be slightly broader in proportion to its length, being 15.5 $\mathrm{mm}$. wide in contrast to 14.3 and $14.5 \mathrm{~mm}$. for the females. The latter are entirely similar in details of the cyphopods.

Distribution: Known so far only from central Alabama, at the edge of the Piedmont. Specimens from slightly to the east, in Talladega County, Ala. (2.7 miles north of Sylacauga, $3 \sigma^{7} \sigma^{7}$, May 5, 1954, L. Hubricht; and 1 mile east of Renfro, $\sigma^{7}$ and +, May 7, 1954, Hubricht), appear to be intermediate in gonopod structure between hubrichti and retrorsus, and are so indicated on the map. These five specimens are very massive; the largest male, $78 \mathrm{~mm}$. long and 16 mm. wide, is the largest North American polydesmoid thus far recorded.

\section{Pachydesmus crassicutis retrorsus Chamberlin}

Figures $1, c, 10, b, 11, b$

Pachydesmus retrorsus Chamberlin, 1921, p. 232, figs. 3, 4.-Chamberlin and Hoffman, 1958, p. 44.

Type specimen: Male (MCZ), from Knoxville, Knox County, Tenn., collected by C. N. Ainslie.

Diagnosis: A very large subspecies of the laticollis phratry, characterized particularly by the rather long and slender primary tibio- 
tarsus of the male gonopod, and the somewhat flattened and massive secondary tibiotarsus, its distal half twisted about 90 degrees to the basal half. The cyphopod resembles that of P.c. hubrichti but lacks the cluster of tubercules on the side of the receptacle.

VARiation: The male specimen from Mentone, Ala., agrees closely with the holotype in gonopod structure as well as other details. The

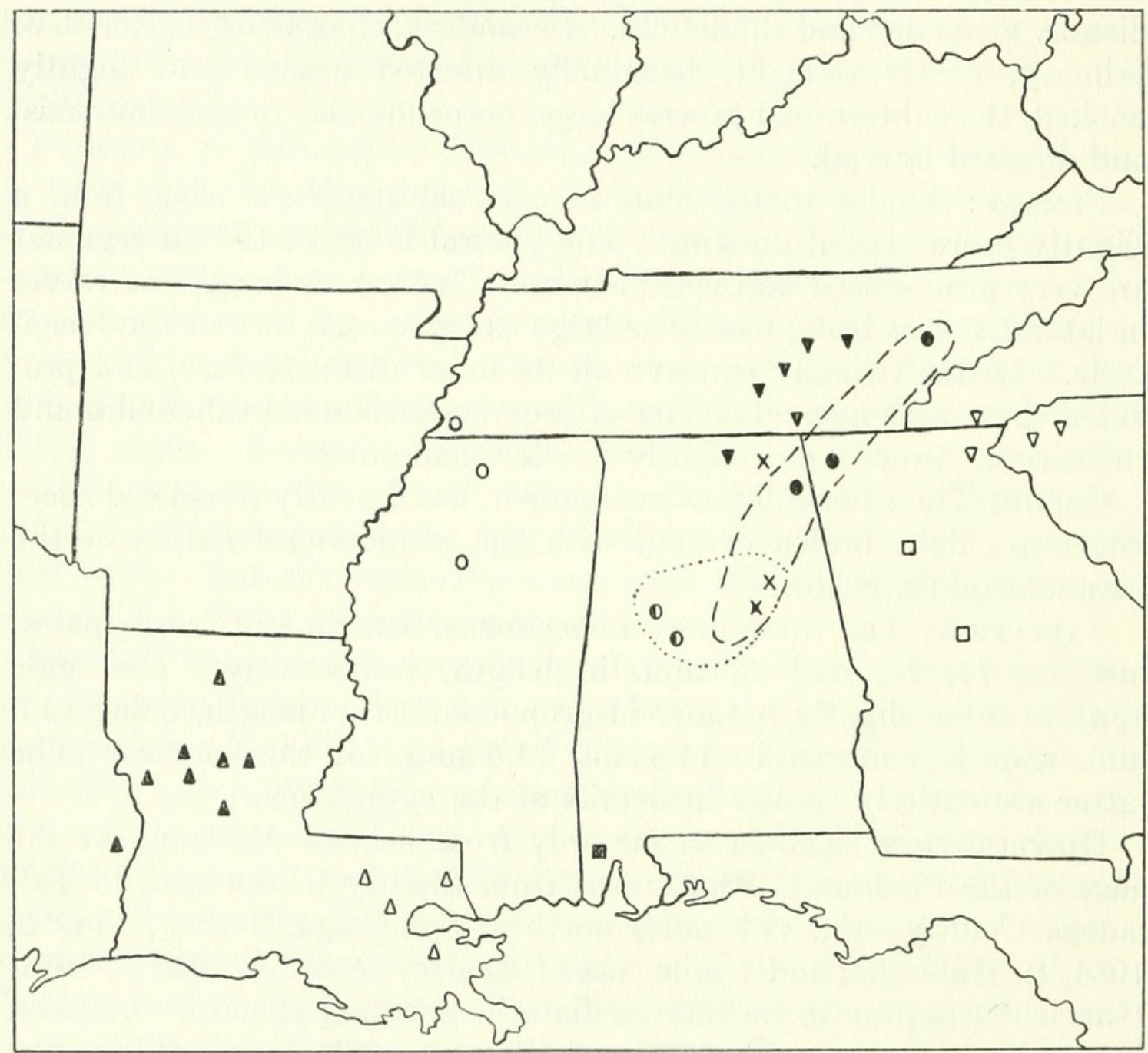

Figure 12.-Distribution of the known forms of Pachydesmus. Solid triangle, P. clarus; hollow triangle, $P$. crassicutis crassicutis; hollow dot, $P$. c. duplex; hollow square, $P . c$. denticulatus; inverted hollow triangle, $P$. c. incursus; solid square, $P$. c. adsinicolus; solid inverted triangle, P. c. laticollis; half-shaded dot, P. c. hubrichti; solid dot, P. c. retrorsus; symbol $\mathrm{X}$, intermediate populations.

apex of the secondary tibiotarsus is directed distad, instead of slightly oblique, and the subterminal process is concealed in mesial aspect. These minor departures, however, are little more than individual variations. Farther south in Alabama, the gonopods become more definitely intermediate between those as figured for retrorsus and hubrichti. The male at hand is $74 \mathrm{~mm}$. in length and $15 \mathrm{~mm}$. in width; the fernale from Georgia is $69 \mathrm{~mm}$. in length. 
Distribution: $P$. c. retrorsus seems to be endemic to the middle portion of the Tennessee Valley, ranging from the vicinity of Knoxville south into adjacent parts of Georgia and northern Alabama. Specimens from the following localities have been examined:

Tennessee. Knox County: Knoxville, $1 \sigma^{7}$, C. N. Ainslie (MCZ, holotype).

Alabama. DeKalb County: Mentone, 1 б $\sigma^{7}$ August 1952, Lindsey S. Olive (RLH).

Georgia. No precise locality, but inferentially from the extreme northwestern corner, 1 \& Apr. 1, 1950, B. D. Valentine (RLH).

\section{Pachydesmus crassicutis adsinicolus, new subspecies}

Figures 10,c, 11,c

Type specimen: Male holotype (USNM 2273) from Mobile, Mobile County, Ala., collected Mar. 29, 1948, by William R. M. Mason.

Diagnosis: One of the smaller members of the laticollis phratry, judging from the dimension of the single known specimen. It is certainly closest to retrorsus, differing chiefly in the shape of the secondary tibiotarsus. In adsinicolus this structure is quite slender and nearly parallel to the primary branch, the two converging distally. In retrorsus the terminal elements of the secondary tibiotarsus are strongly unequal in size and both are directed distad, whereas in adsinicolus the terminal tip is bent mesiad and proximad. The holotype, which is $69 \mathrm{~mm}$. in length and $14.5 \mathrm{~mm}$. in width, agrees in nearly every particular with specimens of retrorsus.

Distribution: Known only from the type locality. This form is of considerable interest in emphasizing the curious north-south distributional pattern of the laticollis phratry. The subspecific name is given in reference to the habitat of the form near Mobile Bay.

\section{RELATIONSHIPS}

Generic relationships: The generic affinities of Pachydesmus are not as obvious as have been surmised by previous investigators. The superficial similarity of the gonopods to those of the species of Harpaphe misled both Attems and Verhoeff to combine the two genera, despite a marked structural dissimilarity in other respects. Actually, Harpaphe is a member of the Rhysodesmus-Boraria complex, it being difficult to separate females of Harpaphe from those of Boraria carolina except by locality. The gonopods in Harpaphe are distinctly diminutive, as is also the gonopod aperture, and I assume that the secondary tibiotarsal process of Harpaphe must be the result of independent convergent evolution.

Attems (1938, p. 151) stated that the genera Takakuwaia (=Xystodesmus), Rhysodesmus, and Pachydesmus are very closely related but 
he did not mention the basis for his opinion. I suspect his association must have been founded upon species really not congeneric with Rhysodesmus limax and Pachydesmus crassicutis, although lumped with them in his rather unwieldly classification.

In my own opinion, the existing genus most closely allied to Pachydesmus is Epeloria (Chamberlin, 1939), at least the species related to E. ficta, E. dela, and E. leiacantha. In this genus the podosterna of the males are produced into distinct transverse ridges, and the collum is definitely broader than the following tergite. The gonopods appear bifid near their ends, an effect readily achieved by the basal coalescence of the primary and secondary tibiotarsi. From a generalized ancestral stock, perhaps similar to $P$. clarus, it is quite feasible to derive two specialized groups, one represented by the large races of $P$. crassicutis, the other by Epeloria talapoosa and its relatives, which have remained small and developed a simplified gonopod but which are otherwise rather similar in body form and coloration to P. crassicutis. Their distribution around the southeastern periphery of the crassicutis group adds a certain amount of credence to the possibility of a common origin. For the present it is sufficient to indicate that if the telopodite of the gonopod of Epeloria ficta, for example, was bifid entirely to the base instead of only halfway, the result would be almost identical to the gonopod of $P$. clarus, and the similarity of body structure is so close that it need scarcely be changed to approximate that of a true Pachydesmus.

Specific relationships: As already implied, P. clarus seems to represent clearly the ancestral stock from which $P$. crassicutis and its subspecies evolved. It presents none of the specializations peculiar to the larger species, such as more complex gonopods, increase in size, broadened collum, and podosternal ridges of the male. Specific evolution has perhaps been accelerated and almost certainly facilitated by the Mississippi flood plain, which so far as now known completely isolates $P$. clarus in the hill parishes of western Louisiana.

The eight recognized subspecies of $P$. crassicutis fall into two distinct ensembles which have been defined above. Of these two phratries, that including crassicutis, duplex, denticulatus, and incursus is the more primitive. The species are smaller, with less specialized genitalia, and occupy peripheral locations on the range of the genus.

During the Cretaceous embayment of the Coastal Plain province, animal life which had occupied that region must have been forced to withdraw to inland areas. Subsequent invasion of the emerged coastal plain would provide the opportunity for the ancestral pachydesmid stock to spread southeastward probably from Ozarkian and Appalachian refuges. The conservative elements remained west of the Mississippi in the form of $P$. clarus, the more aggressive produced 
first the progenitors of the present crassicutis phratry and then the group now recognized as Epeloria. Of the existing pachydesmids, incursus and duplex have gonopods most like those of clarus, and are in fact very similar to each other. They occupy respectively the northwestern and northeastern corners of the generic range, suggesting slightly modified remnants of their ancestral stock. Near the center of the range, a population reinvaded the southern end of the Appalachians along the old north-south course of the Tennessee River. This population evolved a greater size and more complex gonopod structure, and now, as the laticollis phratry, separates the eastern and western subspecies of the older crassicutis phratry.

Attems, Carl Graf

\section{Literature cited}

1899. System der Polydesmiden. II. Denkschr. K. Akad. Wiss. Wien, vol. 68 , pp. 251-435, pls. 12-17.

1938. Fam. Leptodesmidae, Platyrhachidae, Oxydesmidae, Gomphodesmidae, in Das Tierreich, Lief. 69, pp. 1-487, figs. 1-509.

Bollman, Charles Harvey

1888. Notes upon some myriapods belonging to the U.S. National Museum. Proc. U. S. Nat. Mus., vol. 11, pp. 343-350.

Brolemann, Henri W.

1900. Myriapodes d’Amerique. Mém. Soc. Zool. France, vol. 13, pp. 89-131, pls. 6-8.

Causey, Nell Bevel

1955. New records and descriptions of polydesmoid millipeds (Order Polydesmida) from the eastern United States. Proc. Biol. Soc. Washington, vol. 68 , pp. 21-30.

Chamberlin, Ralph Vary

1918a. Two new diplopods from Louisiana. Canadian Ent., vol. 50, pp. 361-363.

1918b. Myriopods from Okefenokee Swamp, Ga., and from Natchitoches Parish, Louisiana. Ann. Ent. Soc. America, vol. 11, No. 4, pp. 369-380.

1921. Chilopods and diplopods from Knox Co., Tennessee. Canadian Ent., vol. 53, No. 10, pp. 230-233.

1939. On some diplopods of the family Fontariidae. Bull. Univ. Utah, biol. ser., vol. 5, No. 3, pp. 1-19, figs. 1-37.

1942. New southern millipeds. Bull. Univ. Utah, biol. ser., vol. 6, No. 8, pp. 1-19, figs. 1-40.

1946. On some millipeds of Georgia. Ent. News, vol. 57, pp. 149-152, figs. 1-9.

Chamberlin, Ralph Vary, and Hoffman, Richard Lawrence

1958. A checklist of the millipeds of North America. Bull. U. S. National Museum, No. 212, iii+ 236 pp.

Cook, Orator Fuller

1895. Introductory note on the classification of Diplopoda, footnote to "The Craspedosomatidae of North America," Ann. New York Acad. Sci., vol. 9, pp. 1-7. 


\section{Loomis, Harold Frederick}

1943. New cave and epigean millipeds of the United States, with notes on some established species. Bull. Mus. Comp. Zool., vol. 92, No. 7, pp. 373-409, figs. $1-18$.

Loomis, Harold Frederick, and Hoffman, Richard Lawrence

1948. Synonymy of various diplopods. Proc. Biol. Soc. Washington, vol. 61 , pp. 51-54.

Pocock, Reginald Innes

1909. Chilopoda and Diplopoda, in Godman and Salvin, Biologia CentraliAmericana, pp. 1-217, pls. 1-15.

Wood, Horatio C.

1864. Descriptions of new species of North American Polydesmidae. Proc. Acad. Nat. Sci. Philadelphia, vol. 13, pp. 6-10.

1865. On the Myriapoda of North America. Trans. American Philos. Soc., WRAY, D. L vol. 13 , pp. $137-248$, figs. 1-61, pls. 1-3.

1950. Insects of North Carolina. Supplement 2, pp. 1-59. 


\section{$2 \mathrm{BHL}$ Biodiversity Heritage Library}

Hoffman, Richard L. 1958. "Revision of the Milliped Genus Pachydesmus (Polydesmida: Xystodesmidae)." Proceedings of the United States National Museum 108(3399), 181-218.

https://doi.org/10.5479/si.00963801.108-3399.181.

View This Item Online: https://www.biodiversitylibrary.org/item/32559

DOI: https://doi.org/10.5479/si.00963801.108-3399.181

Permalink: https://www.biodiversitylibrary.org/partpdf/7088

\section{Holding Institution}

Smithsonian Libraries

\section{Sponsored by}

Smithsonian

\section{Copyright \& Reuse}

Copyright Status: NOT_IN_COPYRIGHT

Rights: https://www.biodiversitylibrary.org/permissions/

This document was created from content at the Biodiversity Heritage Library, the world's largest open access digital library for biodiversity literature and archives. Visit BHL at https://www.biodiversitylibrary.org. 